\title{
Frameworks for Assessing Financial Censorship and Its Implications
}

\author{
Marco Pagani \\ San José State University \\ George Whaley \\ San José State University \\ David Czerwinski \\ San José State University
}

This case explores numerous frameworks to describe and assess issues related to the evolving financial censorship controversy from a stakeholder perspective. The January 6, 2021, Capitol riots, recent mass shootings, controversial use of social media, and other high-profile events have made financial censorship in the U.S. a relevant topic. Some major financial companies have taken steps to ban or curtail legal transactions that may indirectly be associated with criminal acts, hateful speech, immoral conduct, or extreme opinions, while other companies have refrained. The financial industry and its stakeholders are deeply concerned about the legal, ethical, and social responsibility aspects of the controversy and its key challenges, limitations, and consequences. Readers are asked to assess financial censorship employing multiple approaches and models to enrich their understanding of the phenomenon by analyzing its sources, implementation, and impact on industry factors such as governance, technology, and innovation.

Keywords: financial censorship, financial institutions, credit card companies, banks

\section{INTRODUCTION}

The increase in mass shootings, street demonstrations, the January 6, 2021 Capitol riot, and other social upheaval continued to be a compelling test of the social contract and fabric for many U.S. institutions, including financial firms. These changes in the U.S. economic, social, and political climate resulted in the questioning of many legal financial transactions by politicians, financial firms, and other stakeholders. Banning clients or restricting legal transactions brought to the forefront of the American discourse the concept of financial institutions enacting social changes through actions that have been characterized as financial censorship. In several recent instances financial institutions made decisions which tested the boundaries of financial censorship and spurred strong controversies because of their intersection with politically charged issues. 


\section{RECENT POLITICAL INCIDENTS THAT TEST BOUNDARIES OF FINANCIAL CENSORSHIP}

Following the Capitol riot on January 6, 2021, the payment processor Stripe Inc. stopped processing payments for departing President Trump's campaign website, citing violations of policies against encouraging violence (Andriotis, Rudegeair, \& Glazer, 2021). Moreover, Signature Bank, which had catered to the financial needs of the Trump family for several years, decided to close President Trump's personal accounts while calling for his resignation. This New York-based bank stated that it would refuse to do "business in the future with any members of Congress who voted to disregard the Electoral College" (Kollmeyer, 2021). Another recent noteworthy example with political overtones occurred shortly before the September 12, 2019 Democratic debate in Houston, Texas. Then presidential candidate Beto O'Rourke blasted financial institutions for not doing enough to combat gun violence and mass shootings. He blamed this latest dark chapter in U.S. life on the unwillingness of financial institutions and the U. S. Congress to take positive action, and tweeted:

\section{Credit cards have enabled many of America's mass shootings in the last decade-and with Washington unwilling to act, they need to cut off the sales of weapons of war today. Banks and credit card companies must: Refuse to provide services for the sales of assault weapons. Stop processing transactions for gun sales online or at gun shows without background checks. Stop doing business with gun or ammo manufacturers who produce or sell assault weapons (Ernst, 2019).}

Some Republicans (GOP) opposed such an approach and had already prepared to push back against financial institutions that would deny services to firearms businesses selling constitutionally protected products. Several GOP representatives feared that financial firms would position themselves as public policy arbiters, forcing discriminatory policies pertaining to sectors of the economy that were out of favor with "boardroom bureaucrats" (Keane, 2019). In fact, Senators Kevin Cramer (R-ND) and John Kennedy (R-LA) had introduced the Freedom Financing Act, which would revoke deposit insurance for banks and credit unions or sanction with civil penalties card networks if they leveraged " [...] their power and position to effectively illegalize legal commerce by refusing to do business with certain industries and individuals due to their differing political beliefs [...]" (Cramer \& Kennedy, 2019). Although firms in the financial services sector did not directly address the statements of the politicians on the two sides of the aisle, some card processors like Square had already banned transactions involving legal firearms: "We do not believe permitting the sale of firearms on our platform is consistent with our values or in the best interest of our customers" (Ross Sorkin, 2018a). Not all financial industry players agreed that banning controversial legal transactions was warranted. For example, Wells Fargo bank CEO Timothy Sloan said: "We do not think it is a good idea for banks to decide what product or services Americans can buy [...]. It should not be up to me, to us, to decide that. It should be up to the folks following the laws and folks making the decisions" (Andriotis, Demos, \& Glazer, 2018).

Industry observers thought a controversy existed because there were wide differences in beliefs and actions toward monitoring and banning certain legal transactions that were growing and increasingly ending up in the press and social media (Blackwell, 2018). As The Economist described it, "Banks and credit-card companies...are finding themselves playing a bigger role in what is said and done in the public square - to their, and their customers', discomfort" (Credit-card firms are becoming reluctant regulators of the web, 2021). The curtailing of certain legal financial transactions concerning guns might be considered a form of censorship by the average gun customer or seller. Moreover, if financial firms were to ban or severely restrict firearm transactions, what other legal product or services could be banned next? If financial firms de-banked members of one political party, what repercussions would business partisanship create across society? A broad range of people became interested in the controversy as it grew, leaving many of them to wonder about the best framework to understand and assess this controversy. 


\section{COMPETING FRAMEWORKS}

These interested parties or stakeholders were concerned about several aspects of the controversy where researchers had provided frameworks to increase insights and raised critical questions (Carroll, 1979; Freeman, 1984; Goodpaster, 1991; Jamali, 2008; Badaracco, 2016; Laasch, Suddaby, Freeman, \& Jamali, 2020). Were financial institutions disregarding the traditional objective of shareholders' wealth maximization when curtailing or denying legal and profitable transactions initiated by their customers? Without passing judgment on the appropriateness of financial censorship, could this phenomenon be better understood by shifting from a shareholder theory (Friedman, 1970; Freeman, 1984; Goodpaster, 1991) to a more "holistic" stakeholder approach (Carroll, 1979) where legal, regulatory, ethics, and corporate social responsibility considerations are paramount? How could financial censorship be implemented in a fair and efficient way? Should financial institutions strive to adopt industry-wide standards or should each firm independently implement the policies they deem appropriate? If financial censorship was strengthened and expanded to the entire financial sector, then what would the impact be on the level of industry competition and financial innovation? A common thread in the controversy and each framework was the scope of financial censorship and its implications for stakeholders.

\section{FINANCIAL CENSORSHIP: SCOPE, DEFINITION, AND KEY STAKEHOLDERS}

The traditional view of censorship focused on censorship as the opposite of freedom and the principal area of concern was state or institutional repression (Hoffmann, 1989; Freshwater, 2004; Bunn, 2015). However, the notion of censorship was reviewed and evolved, and various definitions and forms emerged. Some scholars viewed censorship through the lens of a process involving relationships between competing agents rather than the traditional view of control through a repressive centralized or state authority (Freshwater, 2004). The new censorship theory evolved to include the process where victims and the repressors intersected along with multiple stakeholders, and cut across various disciplines and stakeholders such as government, communications, technology, business, law, ethics, and public policy. Slowly, the language of censorship grew from "stopping," "repressing," "controlling," and "regulating" to include concepts such as "self-regulating," "gatekeeping," "pressure," and "influencing" (Hoffmann, 1989; Freshwater, 2004; Shoemaker \& Vos, 2009; Vos \& Russell, 2019).

\section{Scope of Financial Censorship}

As mentioned, censorship surfaced as a pivotal issue in many established disciplines and emerging fields of study, and sometimes manifested in subtle ways. Laasch et al. (2020) mentioned that the issue of censorship surfaced in the emerging field of Responsible Management. Gatekeeping, as a proxy for censorship, recently appeared in the field of journalism through the subtle influence of Silicon Valley technology platforms, which engendered self-censorship when reporting the news (Vos \& Russell, 2019). Several business disciplines (e.g., Marketing and Public Relations) and entire industries shared the selfcensorship concerns of many journalists and the news industry.

\section{Definitions of Financial Censorship}

Several definitions of financial censorship were developed for the industry (Electronic Frontier Foundation, 2020; Students for Liberty, n.d.). For example, the Electronic Frontier Foundation (EFF) defined financial censorship as "when financial institutions and payment intermediaries shut down accounts or inhibit transactions" (Electronic Frontier Foundation, 2020). Financial censorship seemed to occur most often when a financial institution, at its own discretion, denies its services to a customer because of that customer's expressed views or line of business. Students for Liberty defined financial censorship as "the restriction of a private entity's financial activity, in such a way as to inhibit their operations, with the implicit intention of rendering them silent" (Students for Liberty, n.d.). Thus, a multi-layered process of selfcensorship, pressure, and influence joined traditional bans on financial activities in the expanding scope of financial censorship. 
The controversy grew as the spotlight of social transformations in the U.S. became more prominent, but it also grew because some major industry participants agreed with financial censorship and others disagreed. The processing of legal transactions resulted sometimes in denial of important services to some customers, curtailment of the right to do business for others, and the perception of arbitrary and capricious actions by some financial firms.

\section{Stakeholders}

Many in the financial industry were equally concerned about how stakeholders were perceived and defined through the financial censorship controversy (Freeman, 1984; Goodpaster, 1991; David, 2009; Jones \& George, 2019). Numerous researchers have linked economics, marketplace, and business activities to stakeholder theory (Carroll, 1979; Freeman, 1984; Goodpaster, 1991; Jamali, 2008; Badaracco, 2016; Laasch et al., 2020). For example, Goodpaster (1991) used a "player" analogy to describe stakeholders, where the stakeholders had a stake in the game and some economic value at risk. The stakeholder framework, once the domain of academics and political or social thinkers, eventually permeated to the business community and came to represent a powerful alternative to the shareholder primacy theory (Friedman, 1970; Freeman, 1984). In fact, in 2019, 181 executives from the Business Roundtable (BR) signed a statement that acknowledged the purpose of a corporation was to serve "all of our stakeholders." As reported in the group's official statement (Table 1), the heads of major U.S. corporations listed as key stakeholders their customers, employees, suppliers, communities, and shareholders.

TABLE 1

\section{STATEMENT BY BUSINESS ROUNDTABLE, AUGUST 2019}

\section{Preamble}

Since 1978, Business Roundtable has periodically issued Principles of Corporate Governance. Each version of the document issued since 1997 has endorsed principles of shareholder primacy - that corporations exist principally to serve shareholders. With today's announcement, the new Statement supersedes previous statements and outlines a modern standard for corporate responsibility.

\section{Statement on the Purpose of a Corporation}

Americans deserve an economy that allows each person to succeed through hard work and creativity and to lead a life of meaning and dignity. We believe the free-market system is the best means of generating good jobs, a strong and sustainable economy, innovation, a healthy environment and economic opportunity for all.

Businesses play a vital role in the economy by creating jobs, fostering innovation and providing essential goods and services. Businesses make and sell consumer products; manufacture equipment and vehicles; support the national defense; grow and produce food; provide health care; generate and deliver energy; and offer financial, communications and other services that underpin economic growth.

While each of our individual companies serves its own corporate purpose, we share a fundamental commitment to all of our stakeholders. We commit to:

- Delivering value to our customers. We will further the tradition of American companies leading the way in meeting or exceeding customer expectations. 
- Investing in our employees. This starts with compensating them fairly and providing important benefits. It also includes supporting them through training and education that help develop new skills for a rapidly changing world. We foster diversity and inclusion, dignity and respect.

- Dealing fairly and ethically with our suppliers. We are dedicated to serving as good partners to the other companies, large and small, that help us meet our missions.

- Supporting the communities in which we work. We respect the people in our communities and protect the environment by embracing sustainable practices across our businesses.

- Generating long-term value for shareholders, who provide the capital that allows companies to invest, grow and innovate. We are committed to transparency and effective engagement with shareholders.

Each of our stakeholders is essential. We commit to deliver value to all of them, for the future success of our companies, our communities and our country.

Source: (Business Roundtable, 2019)

The BR organization also stipulated for the shareholders the purpose was to generate "long-term value" (Business Roundtable, 2019). Financial firms were members of the Business Roundtable with current Chairman Jamie Dimon, CEO of JPMorgan Chase \& Co., making the financial industry a major stakeholder and participant in industry self-regulation. On either side of the financial censorship controversy, banks, credit card firms, customers, politicians, and citizens became uneasy because financial censorship was viewed as inconsistently applied and impacting these stakeholders in different ways. Therefore, would a stakeholder approach help bridge the gap between stakeholders?

\section{FINANCIAL CENSORSHIP ALREADY A REALITY}

Although financial censorship was not a new phenomenon, usually its scope was limited to products or services that most likely had a high risk of fraud, might have contained obscenities, or might be flagged by overzealous regulators during investigations. More recently, "payments have become a tool of domestic and international policy," noted Aaron Klein, a senior fellow at The Brookings Institute (Credit-card firms are becoming reluctant regulators of the web, 2021). Financial institutions and money transfer organizations were expanding the application of financial censorship to specific legal products or were targeting individuals or organizations that espoused legal, but in their opinion controversial or extreme social and political views. Financial censorship was already an industry-wide reality and it impacted stakeholders such as businesses, customers, social media companies, and political activism groups.

Money transfer services like PayPal and Square did not allow their services to be used for the sale of firearms, firearm parts, or ammunition (PayPal, 2020; Square, 2020). Following the February 2018 mass shooting at Marjory Stoneman Douglas High School in Parkland, Florida, Citigroup introduced a new set of rules restricting gun sales by Citigroup's clients. In fact, Citigroup required that its clients put in place a process to restrict the sale of guns to anyone under the age of 21, to stop the sale of high-capacity magazines, and to perform background checks (Ross Sorkin, 2018b).

In other instances, money transfer institutions denied their services due to the controversial nature of opinions expressed by their customers. PayPal stopped processing payments for affiliated stores and donation pages for InfoWars and Gab.com. Rudegeair (2019) reported that PayPal stopped processing payments for the website InfoWars, founded by the provocateur Alex Jones-accused of publishing discredited conspiracy theories - after a company policy review "found instances that promoted hate or discriminatory intolerance against certain communities and religions, which run counter to our core value of inclusion" (Fung, 2018). For Gab, the PayPal ban came after it was revealed that the suspect in the attack on a Pittsburgh synagogue in October appeared to have posted anti-Semitic notes on Gab's messaging platform. Chase Bank closed the personal and business accounts of Texas conservative entrepreneur Enrique Tarrio, the Afro-Cuban chairman of the Proud Boys, without providing substantial and clear motivations (Malkin, 2019). Similarly, PayPal denied services to controversial right-wing figures like Milo 
Yannopolis and Gavin McInnes, founder of the Proud Boys, as well as far-left groups like Antifa-affiliated groups in Atlanta, Philadelphia, and Sacramento (Rudegeair, 2019). Banks like Chase Bank were accused by certain groups of de-banking practices. The Council on American-Islamic Relations (CAIR) claimed racial or ethnic discrimination was an increasing trend of bank account closures based on the results of risk investigations that may have been motivated by customers' identifiable Muslim names or bank transactions with Muslim-majority countries, and not by any actual illegal activity (CAIR, 2017).

GoFundMe, the crowdfunding platform, suspended a fundraiser established by conservative media personality and activist Candace Owens to collect funds for the co-owner of an Alabama café. Michael Dykes, the co-owner of Birmingham's Parkside Café, in a text posted online had disparaged George Floyd, calling him a "thug" and the protesters who manifested against his alleged murder as "idiots." Following these statements, three employees of the café quit and people started boycotting the establishment. Candace Owens started the fundraiser stating that she intended to help an already struggling business that was now facing a boycott. GoFundMe decided to remove the campaign after more than $\$ 200,000$ had been raised. A spokesperson for the fundraising campaign stated that:

\section{GoFundMe has suspended the account associated with Candace Owens and the GoFundMe campaign has been removed because of a repeated pattern of inflammatory statements that spread hate, discrimination, intolerance and falsehoods against the black community at a time of profound national crisis. These actions violate our terms of service, a GoFundMe spokesperson said (Budryk, 2020).}

Instead of closing accounts directly, some financial institutions pressured non-financial institutions to sever ties with their customers for controversial speech. Card networks like Visa and Mastercard were accused of pushing social media platforms to suspend the accounts of controversial media creators. Patreon was a crowdfunding membership platform that provided business tools for content creators to build relationships and receive donations and funding from subscribers. The platform terminated the account of one of its creators, Carl Benjamin, aka Sargon of Akkad, for using a prohibited word in a video on another channel that was not advertised on Patreon. During a call with another media creator, Jaqueline Hart, Trust \& Safety representative at Patreon, implied that Visa and Mastercard, or financial services in general, had rules regarding what was allowed to be funded on the crowdfunding platform (Testa, 2018). In another case, Patreon terminated the account of Robert Spencer, the controversial founder of Jihad Watch, who critics accused of islamophobia. Jihad Watch was a website claiming to be dedicated to bringing public attention to the role that jihad theology and ideology play in the modern world (Jihad Watch, 2020). Patreon tweeted that the account termination was the result of Mastercard's decision: "Hi Robert, we emailed you earlier today which explained that unfortunately Mastercard required us to remove your account. You replied to us but if you have further questions we're happy to keep emailing" (Testa, 2018).

Financial Institutions also denied services to customers who engaged in activities related to the sex industry. For instance, PayPal froze accounts and seized funds belonging to Dee Dennis and Tess Danesi, whose transgression was publishing the NYC Sex Blogger Calendar. Blogger and adult industry writer Cara Sutra was banned for selling a corset. Former escort Vicki Gallas was banned from using PayPal to process payments for her memoirs because they included sex work. In all these cases, the financial institutions claimed that the banning or denial of service was motivated by the assessment of "high risk" related to human sexuality. However, the Federal Deposit Insurance Corporation (FDIC) clarified that such cases were not consistent with regulatory directives (Blue, 2015).

Banks sometimes closed accounts of political candidates based on their controversial advocacy. For example, Wells Fargo bank communicated to Nikki Fried, a Democrat running in 2018 for agriculture commissioner in Florida, that the closure of her accounts was due to her support for medical marijuana and possibly receiving funds from employees and businesses in the medical cannabis industry. Even though medical marijuana was legal in Florida, the bank did not want to be associated with financial transactions that could be interpreted as problematic from a Federal regulatory perspective (Flitter, 2018). Perhaps, the line between sanctioning political opinion and regulatory compliance was blurred in such a case. 


\section{MULTI-FACETED FRAMEWORKS FOR FINANCIAL CENSORSHIP}

Research demonstrated that several stakeholder frameworks exist for analyzing and evaluating social performance (Carroll, 1979; Freeman, 1984; Goodpaster, 1991; Jamali, 2008; Badaracco, 2016; Laasch et al., 2020). Table 2 shows one popular framework consisting of four prioritized responsibilities of business organizations from a stakeholder perspective (Carroll, 1979).

TABLE 2

RESPONSIBILITIES OF BUSINESS ORGANIZATIONS

\begin{tabular}{|c|c|c|}
\hline Priority & Area of Responsibility & Type of Responsibility \\
\hline 1. & Economic & Must do \\
\hline 2. & Legal & Have to do \\
\hline 3. & Ethical & Should do \\
\hline 4. & Discretionary & Might do \\
\hline
\end{tabular}

Source: (Adapted from Carroll, 1979)

This integrated Carroll (1979) model evolved and some components such as ethics and discretionary (social responsibility) were modified. New technology and innovation together with the evolving responsibility management field, forced researchers and practitioners to take a fresh stakeholder view of all aspects of the financial censorship controversy (Jamali, 2008; Badaracco, 2016; Laasch et al., 2020). For example, sometimes credit card companies indirectly enacted financial censorship by pressuring social media platforms. Hence, should new technology, industry innovation, governance, and firms' organizational structure be considered in a more comprehensive view of financial censorship?

The research indicated that stakes, interest, and risk assumed by each stakeholder regarding the goals of a company or industry determined the clout stakeholders had in a situation (Freeman, 1984; Goodpaster, 1991; Jamali, 2008; Badaracco, 2016; Laasch et al., 2020). Research also suggested that stakeholders were the integrating mechanism for most management models related to financial censorship and stakeholder attributes were the preferred technique for determining the most important stakeholder for a specific context (Eesley \& Lenox, 2005; Rothaermel, 2015). There were immediate consequences to areas such as industry governance and innovation.

\section{GOVERNANCE AND ORGANIZATIONAL STRUCTURE FOR FINANCIAL CENSORSHIP}

MacKay and Phillips (2005) indicated the importance of industry governance to firm-level financial and real decisions and concluded that financial structure, technology, and risk were jointly determined within industries. If financial institutions considered that the practices of financial censorship were beneficial to their organizations and society at large, then great attention should be paid to the organizational structure overseeing and promoting such practices. Industry governance could refer to the breakdown of the financial industry into various institutions such as banks, credit card companies, payment processors etc., authority frameworks such as centralization versus decentralization, or the amount and type of regulation. Each of these three definitions of governance had merit. However, Solomon (2010) indicated new governance research tended to focus on regulation theory and practices. Should the financial industry structural response to financial censorship be based on the amount of external or internal regulation or the amount of industry centralization and decentralization?

Governance usually referred to the structure of industries, whereas organizational structure or design usually referred to the structure of individual organizations (Mintzberg, 1993; Osland, Kolb, Rubin, \& Turner, 2007; Solomon, 2010; Jones \& George, 2019). The external and internal forces related to the stakeholder analysis framework (legal, regulatory, ethical, and social responsibility) focused on their impact on the structure and strategy of individual firms involved in financial censorship. Some industry observers noted that external and internal forces on an organization influenced the organizational structure and 
decision-making, and one area of focus was regulation as a key external force on governance and structure (Solomon, 2010). Would the tasks, roles, authority, and responsibilities for implementation of effective and fair financial censorship across financial firms be based on the degree of regulation or centralization? Should financial censorship decisions be handled by the finance unit or should they reside at a different hierarchical level within the firm? Should firms rely on internal resources for the entire decision-making process or should they outsource some of the steps to organizations with "specialized" knowledge of free speech, hate speech, or immoral products? For instance, PayPal supplemented their internal brandreputation group with additional input from the Southern Poverty Law Center, which could provide an external perspective on the type of accounts to close (Rudegeair, 2019). Research showed such organizational structures might need to support the culture of the firm or industry (Mintzberg, 1993; Trice \& Beyer, 1993; Osland et al., 2007).

Because firms faced decisions regarding the optimal degree of structure for decision-making, an alternative approach to individual firm decision-making was to standardize financial censorship practices across the entire industry. Such a heightened degree of centralization would provide standardization of customer treatment across industry players but could possibly stifle diversity of perspectives.

\section{TECHNOLOGY, COMPETITION, AND INNOVATION WITH FINANCIAL CENSORSHIP}

The emergence of financial censorship in the financial industry raised relevant questions about the interaction of changes in structure and innovation at the industry and individual firm levels (Argyres, 1995; Stefanadis, 2003; MacKay \& Phillips, 2005). Furthermore, Yermack (2017) indicated that blockchains represented a novel application of cryptography and information technology to age-old problems of financial record-keeping, and may lead to far-reaching changes in corporate governance.

Independent of the organizational structure designed to implement financial censorship, firms needed to devise operational procedures to detect problematic clients or transactions that could be censored. Given the massive numbers of transactions that each day were cleared by credit card companies, whose values totaled 3,888 billion dollars in 2018, financial firms needed an imposing data gathering and analysis infrastructure (Peter, 2019). Both algorithms and human inputs would be required to vet the nature and the context of speech that may be misconstrued as hateful or discriminatory. Even detecting transactions of certain categories of goods would be challenging, especially when small businesses were involved. Often, firearm sales were classified in broad categories as goods sold by specialty retailers or sporting-goods retailers. Financial services relied on the Merchant Category Code (MCC) and those codes identified the general type of merchant and very seldom the type of merchandise sold. Hence, effective transaction monitoring would require the detailed classification of each product and the creation of specific MCCs (Andriotis, Demos, \& Glazer, 2018). Could sellers' or buyers' privacy or data collection limitations hamper an effective implementation of financial censorship?

Would the impact of financial censorship on the competitive environment of the financial sector be significant? Such impact would depend on whether each firm individually engaged in the practice of financial censorship or whether industry-wide standards were developed. If financial institutions were implementing censorship according to the values espoused by their management, stakeholders, or shareholders, then clients might be driven to patronize firms based on the social values and moral choices. Such economic equilibrium would entail an industry where financial institutions would be chosen not for their level of service, transaction costs, and efficiency but because they catered to a specific political or social ideology and they banned or allowed certain transactions. Therefore, social value and political affiliation could become salient considerations in explaining financial decisions. Would firms thrive based on the popularity of their social activism instead of facing an economic environment where they would be judged on their ability to deliver the best service at the lowest cost?

Finally, firms had to contemplate whether their actions would drive people away from the traditional financial industry into alternatives such as cryptocurrency, where their transactions would be difficult if not impossible to censor. Cryptocurrencies were based on blockchain technology, a distributed, peer-to-peer 
ledger of transactions that did not rely on a centralized financial institution. Would cryptocurrencies provide a viable alternative for customers seeking freedom from financial censorship?

\section{CONCLUSION}

The definition and scope of censorship changed as the complexity of social arrangements and social contracts changed (Hoffmann, 1989; Freshwater, 2004; Bunn, 2015). However, recent changes in the economic, social, and political climate in the U.S. placed a spotlight on financial censorship that grew into a controversy for the financial industry and its stakeholders. The implications of legal financial transactions that were discouraged, restricted, or banned grew and crossed established disciplines such as law, business, and ethics as well as evolving areas of governance, technology, and innovation. The literature showed that the financial censorship controversy lacked a universally accepted lens to view it and propelled the search for a realistic and non-judgmental framework to understand and analyze the phenomenon, and to make recommendations for additional assessment.

The industry focus on financial censorship was different from the traditional company or protagonist focus, and raised fundamental questions starting with the definition of financial censorship and the nature of the controversy. The financial industry took the traditional profit motive framework seriously, but was also concerned about questions related to legality, morality, and inconsistency in the application of financial censorship (Asher, Mahoney \& Mahoney, 2005). This growing controversy raised a wide array of concerns related to the move away from the traditional profit motive or wealth maximization view and focused on factors such as the impact on multiple stakeholders, the impact on competition, governance and innovation in the industry, data gathering infrastructure and cryptocurrency alternatives for maintaining the privacy of transactions. Yet, in spring 2021, the key industry concerns could be identified in several questions: 1 . What was financial censorship and how did it differ from traditional censorship? 2. What were the evolving legal, regulatory, ethical, and social responsibility frameworks for financial censorship? 3. What methods could be used to determine the most important stakeholders in the financial industry related to legal transactions that have been curtailed or banned? 4. How would the implementation of financial censorship impact the industry governance and the companies' organizational structures and procedures?? 5. What consequences would there be on financial innovation, customers' privacy, and competition in the U.S. financial services industry?

\section{ACKNOWLEDGEMENT}

Translated \& edited by American Publishing Services (https://americanpublishingservices.com/).

\section{REFERENCES}

Andriotis, A., Demos, T., \& Glazer, E. (2018, April 30). Banks, credit-card companies explore ways to monitor gun purchases. The Wall Street Journal. Retrieved from https://www.wsj.com/articles/banks-card-companies-explore-ways-to-monitor-gun-purchases1525080600

Andriotis, A., Rudegeair, P., \& Glazer, E. (2021, January 10). Stripe Stops Processing Payments for Trump Campaign Website. The Wall Street Journal. Retrieved from https://www.wsj.com/articles/stripe-stops-processing-payments-for-trump-campaign-website11610319116 ?mod=article_inline

Argyres, N.S. (1995). Technology strategy, governance structure and interdivisional coordination. Journal of Economic Behavior \& Organization, 28(3), 337-358.

Asher, C.C., Mahoney, J.M., \& Mahoney, J.T. (2005). Towards a property rights foundation for a stakeholder theory of the firm. Journal of Management \& Governance, 9(1), 5-32.

Badaracco, J. (2016, September). How to tackle your toughest decisions. The Harvard Business Review. 
Blackwell, R. (2018, February 20). Call for bank crackdown on gun sales is deeply misguided. America Banker. Retrieved from https://www.americanbanker.com/the-call-for-bank-crackdown-on-gunsales-is-deeply-misguided

Blue, V. (2015, December 2). PayPal, Square and big banking's war on the sex industry. The Engadget. Retrieved from https://www.engadget.com/2015-12-02-paypal-square-and-big-bankings-war-onthe-sex-industry.html

Budryk, Z. (2020, June 8). GoFundMe suspends Candace Owens' fundraiser over 'intolerance' policy. The Hill. Retrieved from https://thehill.com/blogs/blog-briefing-room/news/501623-gofundmesuspends-candace-owens-campaign-over-intolerance

Bunn, M. (2015). Reimagining repression: New censorship theory and after. History and Theory, 54(1), $25-44$.

Business Roundtable. (2019, August 19). Business Roundtable Redefines the Purpose of a Corporation to Promote 'An Economy That Serves All Americans'. Retrieved from

https://www.businessroundtable.org/business-roundtable-redefines-the-purpose-of-a-corporationto-promote-an-economy-that-serves-all-americans

CAIR. (2017, October 21). Civil Rights Report 2017: Bank Account Closures. U.S. Islamophobia Network. Retrieved from http://www.islamophobia.org/islamophobic-individuals/stevenemerson/15-reports/198-civil-rights-report-2017-bank-account-closures.html

Carroll, A. B. (1979). A three-dimensional conceptual model of corporate performance. Academy of Management Review, 4(4), 497-505.

Cramer, K., \& Kennedy, J. (2019, March 14). Freedom Financing Act. S.821. Retrieved from https://thehill.com/blogs/congress-blog/politics/438990-senate-bill-seeks-to-bring-freedom-backto-banking

Credit-card firms are becoming reluctant regulators of the web. (2021, October 10). The Economist. Retrieved from https://www.economist.com/finance-and-economics/credit-card-firms-arebecoming-reluctant-regulators-of-the-web/21805450

David, F. (2009). Strategic Management: Concepts and Cases (12th ed). Upper Saddle River, NJ: Pearson Prentice Hall.

Eesley, C., \& Lenox, M.J. (2005, August). Firm Responses to Secondary Stakeholder Action. In Academy of Management Proceedings (Vol. 2005, No. 1, pp. E1-E6). Academy of Management.

Electronic Frontier Foundation. (2020). Financial Censorship. Retrieved from https://www.eff.org/issues/financial-censorship

Ernst, D. (2019, September 12). Beto demands banks, credit card companies 'cut off' firearms sales to law-abiding citizens. The Washington Times. Retrieved from https://www.washingtontimes.com/news/2019/sep/12/beto-orourke-demands-banks-credit-cardgiants-cut-/

Flitter, E. (2018, August 22). A candidate backed medical marijuana. Wells Fargo closed her bank account. The New York Times. Retrieved from https://www.cnbc.com/2018/08/22/wells-fargocloses-bank-account-of-candidate-who-supports-marijuana.html

Freshwater, H. (2004). Towards a redefinition of censorship. In Censorship \& Cultural Regulation in the Modern Age (pp. 217-237). Brill Rodopi.

Friedman, M. (1970, September 13). A Friedman Doctrine: The Social Responsibility of Business is to Increase Its Profits. The New York Times Magazine. Retrieved from https://www.nytimes.com/1970/09/13/archives/a-friedman-doctrine-the-social-responsibility-ofbusiness-is-to.html

Freeman, E. (1984). Strategic Management: A Stakeholder Approach. Pitman.

Fung, B. (2018, September 21). PayPal bans Alex Jones, saying Infowars 'promoted hate or discriminatory intolerance'. The Washington Post. Retrieved from https://www.washingtonpost.com/technology/2018/09/21/paypal-bans-alex-jones-sayinginfowars-promoted-hate-or-discriminatory-intolerance/?noredirect=on 
Goodpaster, K. (1991, January). Business Ethics and Stakeholder Analysis. Business Ethics Quarterly, $1(1), 53-73$.

Hoffmann, F.W. (1989). Intellectual Freedom and Censorship: An Annotated Bibliography. Scarecrow Press.

Jamali, D. (2008). A stakeholder approach to corporate social responsibility: A fresh perspective into theory and practice. Journal of Business Ethics, 82(1), 213-231.

Jihad Watch. (2020, September 26). Why Jihad Watch? Retrieved from https://www.jihadwatch.org/whyjihad-watch

Jones, G., \& George, J. (2019). Essentials of contemporary management. New York, NY: McGraw-Hill Irwin.

Keane, L. (2019, April 15). Senate bill seeks to bring freedom back to banking. The Hill. Retrieved from https://thehill.com/blogs/congress-blog/politics/438990-senate-bill-seeks-to-bring-freedom-backto-banking

Kollmeyer, B. (2021, January 12). Trump reportedly dumped by lenders Deutsche Bank and Signature. MarketWatch. Retrieved from https://www.marketwatch.com/story/banks-that-have-donebusiness-with-trump-start-to-distance-themselves-11610444427

Laasch, O., Suddaby, R., Freeman, R.E., \& Jamali, D. (Eds.). (2020). Research Handbook of Responsible Management. Edward Elgar Publishing.

MacKay, P., \& Phillips, G.M. (2005). How does industry affect firm financial structure? The Review of Financial Studies, 18(4), 1433-1466.

Malkin, M. (2019, April 17). Are Chase Bank's Account Decisions Motivated by Politics? The Daily Signal. Retrieved from https://www.dailysignal.com/2019/04/17/are-chase-banks-accountdecisions-motivated-by-politics/

Mintzberg, H. (1993). Structure in fives: Designing effective organizations. Englewood Cliffs, New Jersey: Prentice Hall.

Osland, J.S., Kolb, D.A., Rubin, I.M., \& Turner, M.E. (2007). Organizational behavior: An experiential approach. Upper Saddle River, New Jersey: Pearson-Prentice-Hall.

PayPal. (2020, September 26). FAQ - What is PayPal's policy on transactions that involve firearms? Retrieved from https://www.paypal.com/us/smarthelp/article/what-is-paypal\%E2\%80\%99s-policy-ontransactions-that-involve-firearms-faq585

Peter, B. (2019, September 2). Market Share by Credit Card Network. WalletHub. Retrieved from https://wallethub.com/edu/cc/market-share-by-credit-card-network/25531/

Ross Sorkin, A. (2018a, February 19). How Banks Could Control Gun Sales if Washington Won't. The New York Times - Deal Book. Retrieved from https://www.nytimes.com/2018/02/19/business/banks-gun-sales.html

Ross Sorkin, A. (2018b, March 26). Citigroup Acted. Now, Two New Ideas on How Banks Can Limit Gun Sales. The New York Times. Retrieved from https://www.nytimes.com/2018/03/26/business/citigroup-guns.html

Rothaermel, F.T. (2015). Strategic Management Concepts (4e). New York, NY: McGraw Hill.

Rudegeair, P. (2019, February 24). PayPal CEO Grapples with Fringe Groups. The Wall Street Journal. Retrieved from https://www.wsj.com/articles/paypal-ceo-grapples-with-fringe-groups11551016800

Shoemaker, P.J., \& Vos, T. (2009). Gatekeeping Theory. Routledge.

Solomon, J.M. (2010). New governance, preemptive self-regulation, and the blurring of boundaries in regulatory theory and practice. Wis. L. Rev., 591.

Square. (2020, September 26). Prohibited Goods and Services with Square Point of Sale. Retrieved from https://squareup.com/help/us/en/article/5089-prohibited-goods-and-services-with-square-point-ofsale

Stefanadis, C. (2003). Self-regulation, innovation, and the financial industry. Journal of Regulatory Economics, 23(1), 5-25. 
Students For Liberty. (n.d.). Financial Censorship. Retrieved from https://studentsforliberty.org/northamerica/blog/freedom-of-expression/financial-censorship/

Testa, K. (2018, December 27). Patreon Purge: Bankers are the Global Speech Police. The Libertarian

Republic. Retrieved from https://thelibertarianrepublic.com/patreon-purge-bankers-are-theglobal-speech-police/

Trice, H.M., \& Beyer, J.M. (1993). The cultures of work organizations. Englewood Cliffs, NJ: PrenticeHall, Inc.

Vos, T.P., \& Russell, F.M. (2019). Theorizing journalism's institutional relationships: An elaboration of gatekeeping theory. Journalism Studies, 20(16), 2331-2348.

Yermack, D. (2017). Corporate governance and blockchains. Review of Finance, 21(1), 7-31.

\section{INSTRUCTOR' S MANUAL: FRAMEWORKS FOR ASSESSING FINANCIAL CENSORSHIP AND ITS IMPLICATIONS}

\section{Case Synopsis}

This case explores numerous frameworks to describe and assess issues related to the evolving financial censorship controversy from a stakeholder perspective. The January 6, 2021 Capitol riots, recent mass shootings, controversial use of social media, and other high-profile events have made financial censorship in the U.S. a relevant topic. Some major financial companies have taken steps to ban or curtail legal transactions that may indirectly be associated with criminal acts, hateful speech, immoral conduct, or extreme opinions while other companies have refrained. The financial industry and its stakeholders are deeply concerned about the legal, ethical, and social responsibility aspects of the controversy and its key challenges, limitations, and consequences. Readers are asked to assess financial censorship employing multiple approaches and models to enrich their understanding of the phenomenon by analyzing its sources, implementation, and impact on industry factors such as governance, technology, and innovation.

\section{Course and Levels for Which the Case Is Intended}

This case is most appropriate for undergraduate and graduate courses in financial markets and institutions, corporate social responsibility, business law, and ethics. The case is presented in a descriptive format, exploring frameworks for describing and assessing issues related to its concept, controversy, and application of financial censorship for legal financial transactions in the U.S.

\section{Case Learning Objectives}

In completing this assignment, students should be able to:

1. Define financial censorship and compare it to other forms of censorship.

2. Explain the evolving legal, regulatory, ethical, and social responsibility frameworks for financial censorship in the financial industry.

3. Evaluate the challenges of key stakeholders in the financial transactions space.

4. Evaluate the consequences of effective financial censorship on industry governance and organizational structure.

5. Examine the consequences of effective financial censorship on innovation, competitive environment and customers' privacy.

\section{Associated Reading and Assignments}

The target student audience stated in instructor's manual (IM) Section 2, "Course and levels for which the case is intended," has most likely covered the fundamental concepts in several undergraduate or graduate level courses such as management, finance, and business law. The financial censorship area is rather new; however, the tools and techniques for describing and assessing the general area of censorship and the controversy surrounding financial censorship are not new. If students lack sufficient background in the required topic areas, then a basic background for the assignment is covered in several key textbooks 
and articles listed in IM Section 11, Notes and References (Carroll, 1979; Hoffmann, 1989; Goodpaster, 1991; Freshwater, 2004; Asher, Mahoney, \& Mahoney, 2005; Kickul \& Lyons, 2012; Osland, Kolb, Rubin, \& Turner, 2007; David, 2009; Rothaermel, 2015; Bunn, 2015; Jones \& George, 2019 \& Collins, 2019).

\section{Discussion Questions}

This descriptive case study takes a critical yet non-judgmental look back at the evolving area of financial censorship and assesses forces that acted on stakeholders in the controversy. The case explores numerous frameworks to describe and assess issues related to the evolving financial censorship controversy from an industry stakeholder perspective and discusses its key challenges, limitations, and consequences. The challenges of implementing financial censorship and its impact on the industry governance, competition, and innovation are also analyzed. Additionally, the case focuses on the financial industry as opposed to the traditional case viewpoint of an individual organization, protagonist, or decision-maker. Five specific discussion questions (DQs) were developed to achieve the five learning objectives (LOs) through class discussion and written assignments. Each DQ is associated with an appropriate learning objective (LO). IM Section 8, "Conceptual Analysis," provides research support and a brief summary of the appropriate data, theory, concepts, and government regulations used as background in all five sample responses.

The five specific discussion questions are:

1. What is financial censorship and how does it differ from other forms of censorship? (LO1)

2. What are the evolving legal, regulatory, ethical, and social responsibility frameworks for financial censorship in the U.S. financial services industry? (LO2)

3. What methods can be used to determine the most important stakeholders in the financial industry related to legal transactions that have been curtailed or banned? (LO3)

4. What are the possible consequences of financial censorship on financial services industry governance and the company organizational structures and procedures necessary to implement financial censorship? (LO4)

5. What are the possible consequences of financial censorship on financial innovation, customers' privacy, and competition in the U.S. financial services industry? (LO5)

\section{Research Method}

The co-authors do not have an ownership, employee, or consultant relationship with any firm or government entity mentioned in the case. Information contained in the case was gathered entirely from published secondary sources such as on-line research articles, books, government documents, newspapers, and financial trade journals. Nothing in the case is disguised.

\section{Teaching With the Case}

The case would make an excellent end-of-term written assignment for classes pertaining to business law, financial institutions, ethics, social responsibility, or business policy. As an individual written assignment, a minimum of two pages per written question is recommended to cover the relevant theory, concepts, suggested solutions, and the best recommendation or option for each response. Additionally, the case could be effective as either an individual or a group class discussion assignment. As a team assignment, each team member could be held accountable for all five questions or selected teams could be assigned different questions from the list in IM Section 5 "Discussion." It might take longer to process all five questions in classes with more than 3-5 teams or 20-25 students. Additional frameworks and methods are covered in the Additional Teaching Approaches section that follows and stretch exercises are suggested for topics or questions beyond the scope of each required discussion question.

Ideally, the case should be assigned after students have been exposed to courses and readings covering the U.S. Constitution, federal and state laws pertaining to privacy, and associated management models pertaining to stakeholder analysis and censorship. IM Section 4, "Associated Reading and Assignments," lists the pertinent courses and basic readings students would need to answer the assigned discussion questions. Additionally, the instructor might consider a brief lecture or handout on topics covered by each 
question to maximize the written and class discussion experience. For seminar classes of greater than 90 minutes, a more in-depth discussion of the key frameworks and stakeholder models could be explored. It is estimated to take a minimum of thirty minutes to examine each question in a class discussion format; hence, five discussion questions (DQs) would take 2.5 hours class to discuss. The case would be best-used in seminar classes, allowing at least 3-4 four hours for set-up, introduction to the case, and to then cover the case in its entirety. Classes with less time might consider assigning one or two questions per class session.

\section{Additional Teaching Approaches}

The teaching plan is built around the assessment of financial industry actions through spring 2021 and asking students to make suggested improvements. Because this is a controversial topic, one intent of the teaching plan is to draw out multiple approaches from the students and test these approaches for feasibility. Therefore, our use of multiple frameworks, models, concepts, and tools is designed to encourage students to explore multiple approaches and enrich the discussion. Thus, the Controversy $\rightarrow$ Definition $\rightarrow$ Frameworks $\rightarrow$ Consequences flow could form the board plan for instructors that use the boarding technique.

The Conceptual Analysis (CA) section provides an overview of the theory and models used across the discussion questions. The five discussion questions focus on the scope, evolution, and definition of financial censorship, numerous frameworks to describe and assess issues related to the evolving financial censorship controversy from an industry stakeholder perspective, and its key challenges, limitations, and consequences for industry data analysis and governance. Several stretch assignments are provided as a guide for instructors who want to extend the class learning experience beyond the five DQs. Therefore, stretch questions are provided in areas where insufficient information exists in the case, gaps in the case or literature exist, or pertinent methods are beyond the intended scope of the question.

Stretch exercises and additional questions could help refine students' understanding of the definition of financial censorship in DQ \#1. For example, what are the boundaries for the scope of financial censorship? If the student's answer is contingent upon the discipline (law, religion, finance, or marketing) or the stakeholder role, several additional questions or exercises would help tease out the nuances. The students might be asked to categorize the examples in the case according to whether the financial institution was acting in a business-client role or in an intermediary role. Students can be asked: Does the role that the institution plays have an effect on students' views of the appropriateness of the censorship? If a government pressures a financial firm to perform censorship, is that government censorship or financial censorship?

The Carroll (1979) model was included in the case and used in DQ \#2 to explore four different frameworks for analyzing the responsibilities of business organizations (see Case Table 2). Additionally, the Carroll (1979) model has been modified to include the evolving area of responsibility management. Because the case suggested that multiple stakeholders were key players in the financial censorship controversy and customers were the most important major stakeholder, a stretch question regarding a stakeholder-by-stakeholder analysis would expand the scope of DQ \#2. The five-dimension Dahlsrud (2008) model mentioned in the CA was also mentioned in DQ \#2. This model is beyond the intended scope of the question and could be used to analyze the financial censorship controversy from perspectives other than customers. Alternative theories and models, such as the balanced scorecard multiple stakeholder approach, could also be added to compare results and expand student discussion.

The CA indicated that non-quantitative and quantitative decision analysis methods could be used to select the most important stakeholder. A non-quantitative method was used in DQ \#3 to select "customer" as the most important stakeholder but insufficient information existed in the case to use quantitative techniques. It is suggested that students with a quantitative background might gather additional industry data and student-generated estimates, and use a quantitative technique such as the weighted average decision matrix (WADM) with the seven attributes and eight stakeholders listed in Table 1 to improve the stakeholder selection process.

Moreover, an extended stakeholder analysis might be assigned as a stretch exercise. If a rank order or a weight for relative importance could be assigned to each one of the seven attributes, then it would permit the straightforward weighted average decision matrix (WADM) quantitative method to be used by students. 
Each weighted attribute (1-7) would be multiplied by rank (1-8) for each stakeholder and the lowest score would represent the most important stakeholders and scores in the Table 1 template.

TABLE 1

SOURCE OF STAKEHOLDERS TEMPLATE

\begin{tabular}{|l|l|l|l|l|l|l|l|l|}
\hline Stakeholder & S1 & S2 & S3 & S4 & S5 & S6 & S7 & S8 \\
\hline Weights & $\mathbf{1 - 8}$ & $\mathbf{1 - 8}$ & $\mathbf{1 - 8}$ & $\mathbf{1 - 8}$ & $\mathbf{1 - 8}$ & $\mathbf{1 - 8}$ & $\mathbf{1 - 8}$ & $\mathbf{1 - 8}$ \\
\hline 1. Power & & & & & & & & \\
\hline 2. Legitimacy & & & & & & & & \\
\hline 3. Urgency & & & & & & & & \\
\hline 4. Timing & & & & & & & & \\
\hline 5. Control & & & & & & & & \\
\hline 6. Amount & & & & & & & & \\
\hline 7. Risk & & & & & & & & \\
\hline Total & & & & & & & & \\
\hline
\end{tabular}

Source: Authors' notes, 2020

If instructors want to complete the stretch exercise, then the student exercise score (1) could be compared to the instructor's scores (2) in Table 2 for class discussion.

TABLE 2

STAKEHOLDERS PRIORITY TEMPLATE

\begin{tabular}{|l|l|l|l|}
\hline Stakeholder & Student Priority Score (1) & Instructor Priority Score (2) & Justification/Discussion \\
\hline S1 & & & \\
\hline S2 & & & \\
\hline S3 & & & \\
\hline S4 & & & \\
\hline S5 & & & \\
\hline S6 & & & \\
\hline S7 & & & \\
\hline S8 & & & \\
\hline
\end{tabular}

Source: Authors' notes, 2020

\section{Conceptual Analysis}

General Overview

The case covers recent U.S. events that have contributed to the controversy surrounding the evolving area of financial censorship. Problem areas that contribute to the controversy are: definition and evolving scope of financial censorship, lack of a universally accepted framework to assess the controversy, instability of the single stakeholder model for profit maximization, and internal and external concerns about industry governance and technological innovation. Thus, the assessments and improvements suggested in the discussion questions (DQs) rely mainly on sources from the fields of financial markets and institutions, corporate social responsibility, business law, and ethics. This Conceptual Analysis (CA) area is a summary of relevant research literature, theory, and models that support the five discussion questions. The Conclusion component of each discussion question and Additional Teaching Approaches section include theories and models that are pertinent but beyond the intended scope of the case and IM. 


\section{Definition of Censorship}

There is an abundance of research literature and models that cover the general field of censorship (Hoffmann, 1989; Freshwater, 2004; Bunn, 2015). The definition and scope of censorship changed as the complexity of social arrangements and social contracts changed (Hoffmann, 1989; Freshwater, 2004; Bunn, 2015). Censorship can be performed by a wide range of institutions and individuals, which leads researchers to a multiple stakeholder view. Government censorship is perhaps the most visible form of censorship and in some situations, governments have pressured financial institutions to censor transactions (Kreimer, 2006; Keating, 2014; Wu, 2006). Recent changes in the economic, social, and political climate in the U.S. placed a spotlight on legal financial transactions that are discouraged, delayed, or denied, and this incongruity grew into a controversy for the financial industry and its stakeholders. Alternatively, the evolving field of financial censorship is under-researched; yet, there is growing agreement in the financial industry that censorship happens when a financial institution, at its own discretion, denies its services to a party because of that party's expressed views or line of business. Thus, the literature suggests a multi-layered process of self-censorship, pressure, and influence have joined traditional bans on financial activities in the expanding scope of financial censorship, and this approach is reflected in the sample response to DQ \#1.

\section{Alternative Frameworks to Assess Financial Censorship}

The traditional view of the role of profit for a business organization emanates from the laissez-faire economics school of thought that emphasizes profit as the only goal of the business enterprise (Wheelen \& Hunger, 2006). The most prominent spokesperson for the view is Milton Friedman who stated: "There is one and only one social responsibility of business - to use its resources and engage in activities designed to increase its profits so long as it stays within the rules of the game, which is to say, engages in open and free competition without deception or fraud" (Friedman, 1970; Friedman, 2009). The financial field has translated this viewpoint as the traditional shareholder wealth maximization principle (Wheelen \& Hunger, 2006; Collins, 2019). A plethora of strategy, financial, and management scholars contend that this traditional view of shareholder wealth maximization (profit) is limiting and outdated (Carroll, 1979; Asher et al., 2005; McWilliams, Siegel, \& Wright, 2006; Kickul \& Lyons, 2012; Collins, 2019). Furthermore, Asher et al. (2005) indicate the traditional economic perspective of maximizing shareholder wealth is increasingly unsatisfactory for accurately answering the two fundamental questions concerning the theory of the firm: economic value creation and the distribution of that economic value. Carroll (1979) proposes a model (see Case Table 2) that emphasizes managers of business organizations have four responsibilities in priority order: economic (must do), legal (have to do), ethical (should do), and discretionary (might do) that addresses these two fundamental questions.

The economic category is similar to the shareholder wealth maximization (profit) view and some scholars have combined several of the categories such as legal and regulatory, and the ethical and discretionary categories combined as social responsibility (Carroll, 1979). More recently, management scholars have teased out corporate social responsibility (CSR) as a separate form of social engagement and CSR is similar to the discretionary category in the Carroll model (Carroll, 1979; McWilliams et al., 2006; Kickul \& Lyons, 2012). Although the seminal Carroll (1979) model has been modified, the priority or importance of each category has not changed and we have concluded that firms with financial censorship in priority 1 area have less discretion and less risk than priority 4. The modified Carroll model was highlighted in DQ \#2 to assess the legal, regulatory, ethical, and social responsibility implications of this censorship controversy in today's changing social and political environment.

Ethical models and alternative theories and models, such as the balanced scorecard, triple bottom line, and multiple stakeholder approaches, could be added for additional insights and to expand student discussion (Kaplan \& Norton, 1996; Lawrence \& Weber, 2014; Elkington, 2018; Jones \& George, 2019; Collins, 2019). The case suggested that multiple stakeholders were key players in the financial censorship controversy and customers were selected as the most important stakeholder in DQ \#3. The five-dimension Dahlsrud (2008) model was mentioned but not used in DQ \#2 or DQ \#3 because it was beyond the intended scope of the questions; however, the model was included in the list of stretch questions that could be used to analyze the financial censorship controversy from stakeholder perspectives other than customers. Recent 
studies in the emerging responsibility management field have modified the ethical and social responsibility components of the Carroll (1979) model (Jamali, 2008; Laasch, Suddaby, Freeman, \& Jamali, 2020). The emerging field of responsibility management is unsettled and beyond the intended scope of this case study but it has the potential to flesh out nuances in all aspects of the financial censorship controversy.

\section{Evolution of Stakeholder Approach}

A stakeholder is generally described as any entity that can benefit or lose from the strategic goals of a firm (Freeman, 1984; David, 2009; Jones \& George, 2019). Stakeholder theory and models are covered in most standard textbooks used in the management courses listed in the IM (David, 2009; Jones \& George, 2019; Rothaermel, 2015). Additionally, numerous researchers have linked economics, marketplace, and business activities to stakeholder theory (Carroll, 1979; Freeman, 1984; Goodpaster, 1991; Jamali, 2008; Badaracco, 2016; Laasch et al., 2020). Goodpaster (1991) suggests stakeholder analysis does not usually impact decision-making or action and offers a more substantive approach (stakeholder analysis versus stakeholder synthesis) to make stakeholder decisions, especially in the ethics area. Stakeholder synthesis is more strategic and action-oriented than stakeholder analysis, and Goodpaster's decision-making framework (called PASCAL) tends to be useful when stakeholders are to be viewed as multi-fiduciaries (Goodpaster, 1991). Badaracco (2016) extends this approach with a set of five questions that allow for step-by-step decision-making.

Usually, stakeholders can be divided into primary and secondary categories depending on their stake or interest in the goals and transactions of the firm. Primary stakeholders are thought to have higher stakes and interest in the goals of an organization or industry than secondary stakeholders and, over time, secondary stakeholders can become primary stakeholders (Freeman, 1984; Goodpaster, 1991; Jamali, 2008; Badaracco, 2016; Laasch et al., 2020). Hence, it is useful to identify primary stakeholders as the most important stakeholders in any situation (David, 2009; Jones \& George, 2019; Rothaermel, 2015; Wheelen \& Hunger, 2006). Several models and methods exist to identify primary and secondary stakeholders. Wheelen and Hunger (2006) use a three-step process of identifying direct, indirect, and degree-of-interest to classify stakeholders into primary and secondary categories. Research suggests that stakeholder attributes are preferred for determining the most important stakeholder for a specific context (Eesley \& Lenox, 2005; Rothaermel, 2015). One non-quantitative model suggested in the research goes beyond the Wheelen and Hunger (2006) three-step process and is a five-step process to recognize and address stakeholders' claims, and requires decision-makers to pay attention to the list of attributes at each stage (Rothaermel, 2015). This non-quantitative, step-by-step approach was used in DQ \#3 to select "customers" as the most important stakeholder from the stakeholders mentioned in the case (see Case Table 2).

Stakeholder attributes, interests, and priorities together with quantitative decision analysis methods can be a numerical approach and perhaps a more accurate method for finding the most important stakeholder. The expected value (EV) and weighted average decision matrix (WADM) are two such quantitative methods. Quantitative methods would require providing different weights or probabilities to the importance of each attribute and weights or rankings to each stakeholder to determine the most important stakeholder involved in the financial controversy (Osland et al., 2007). Both EV and WADM are beyond the intended scope of DQ \#3; however, the WADM method is described in the Additional Teaching Approaches component of this IM as a student stretch exercise.

\section{Governance and Structure}

The governance concept usually refers to the structure of industries and the organizational structure or design concept refers to the structure of individual organizations (Mintzberg, 1993; Osland et al., 2007; Solomon, 2010; Jones \& George, 2019). Because this case focuses on the financial industry, the impact of financial censorship on the governance or structure of the financial industry is one immediate consequence as pointed out in the case. Some authors approach industry governance and structure from the aggregation of businesses in strategic alliances and B2B networks around common interests (Jones \& George, 2019). However, industry governance could refer to the breakdown of the financial industry into various functional sub-units: e.g., banks, credit card companies, payment processors etc.; authority relationships such as 
centralization versus decentralization; or the amount and type of external and internal regulation. Each type of governance is covered in the literature and has merit for the investigation of financial censorship; however, new governance research tends to focus on regulation theory (Solomon, 2010). Hence, the degree of government versus self-regulation will dominate our discussion in DQ \#4. Although individual firm structure has a lesser focus in the case and IM, it is important to recognize that changes in the structure of the financial industry have the capacity to impact the structure of individual firms that are involved with financial censorship. The MacKay and Phillips (2005) study indicates the importance of industry to firmlevel financial and real decisions, and shows that financial structure, technology, and risk are jointly determined within industries. External and internal forces on an organization influence its organizational structure and decision-making, and industry structure is one of the many external forces. PEST, SWOT, and stakeholder analyses are traditional strategic management concepts that make a systematic analysis of many external forces on the strategic decisions of a company (Freeman, 1984; David, 2009; Rothaermel, 2015). The stakeholder analysis framework was used throughout the case; therefore, this framework was used in DQ \#2 and DQ \#4 to discuss the legal, regulatory, ethical, and social responsibility forces and their impact on the structure and strategy of individual firms involved in financial censorship.

\section{Technology and Innovation}

As previously mentioned, research indicates the importance of industry to firm-level financial and real decisions, and it shows that financial structure, technology, and risk are jointly determined within industries (Argyres, 1995; MacKay \& Phillips, 2005). The Stefanadis (2003) study is also relevant because it suggests continuous innovation may be one of the driving forces of financial industry governance through selfregulation. Yermack (2017) goes a bit further and indicates that blockchains, which incorporate cryptography and information technology to fundamentally change the way financial record-keeping is performed, may lead to far-reaching changes in corporate governance. The lower cost, greater liquidity, more accurate record-keeping, and transparency of ownership offered by blockchains may significantly upend the balance of power among firms in the industry (Yermack, 2017). Thus, the emergence of financial censorship in the financial industry opens the door to changes in structure and innovation at the industry and individual firm levels, and this interaction is discussed in DQ \#4 and DQ \#5.

Research related to the consequences of financial censorship for technologies such as social media, data analysis, and blockchain on financial innovation, customer's privacy, and competition in the U.S. financial services industry are the focus of DQ \#5 (Yermack, 2017; Keats Citron, 2018; Sater, 2019; Tusikov 2019). To be able to monitor the types of purchases on the financial network, the Merchant Category Codes (MCC) should be revised to have finer definitions about the nature of the merchant. Most likely, the MCC system would not be appropriate for large retailers that sell firearms, sporting goods, or other consumer products. Hence, a standardized database of SKU-level data would need to be developed (Ross Sorkin, 2018b). In addition to the creation of a new database and monitoring technologies relying on artificial intelligence and machine learning, effective financial censorship could speed up the adoption by consumers of new payment technologies like cryptocurrencies (Devoe, 2019).

\section{Possible Answers to Discussion Questions}

\section{What Is Financial Censorship and How Does It Differ From Other Forms of Censorship? (LO1)}

Censorship can be performed by a wide range of institutions and individuals, which has led researchers to a multiple stakeholder view. Government censorship is perhaps the most visible form of censorship and in some situations, governments have pressured financial institutions to censor transactions (Kreimer, 2006; Keating, 2014; Wu, 2006). Recent changes in the economic, social, and political climate in the U.S. have placed a spotlight on legal, financial transactions that are discouraged, delayed, or denied, and this incongruity has grown into a controversy for the financial industry and its stakeholders.

Financial censorship occurs when a financial institution denies its services to a party because of that party's expressed views, actions, or line of business. The Electronic Frontier Foundation (EFF) defines financial censorship as "when financial institutions and payment intermediaries shut down accounts or inhibit transactions" (EFF, 2020). Students for Liberty defines financial censorship as "the restriction of a 
private entity's financial activity, in such a way as to inhibit their operations, with the implicit intention of rendering them silent" (Students for Liberty, n.d.). Thus, the literature suggests that a multi-layered process of self-censorship, pressure, and influence have joined traditional bans on financial activities in the expanding scope of financial censorship.

By financial censorship, we specifically mean censorship enacted by corporations in the financial sector. In some cases, governments have pressured financial institutions to censor transactions (Kreimer, 2006; Keating, 2014; Wu, 2006). Seth Kreimer refers to this as "censorship by proxy" (Kreimer, 2006).

In some instances, a financial institution primarily plays the role of intermediary, enabling a transaction between two other parties (one of whom is the financial institution's customer). For example, a credit card company plays the role of intermediary between a buyer and a seller. In other cases, the financial institution is providing services to a client, but is not acting as an intermediary: e.g., a bank that offers a savings account to a customer. When a bank closes or refuses to offer an account, this form of financial censorship is sometimes referred to as "debanking" (Project Veritas, 2019; DeVoe, 2019).

The rise of online transactions has made the issue of financial censorship more acute. Many nonfinancial companies in the online space can also censor, including internet service providers (ISPs), web hosting companies, social media companies, and search engines. A broader look at the various forms and mechanisms for online censorship, including a brief history, may be found in Bambauer (2012). Social media companies have recently come under increased pressure to play the role of gate-keepers, i.e., to ensure the quality or veracity of content posted on their sites, which is related to but distinct from the role of censor (Leetaru, 2019).

Financial censorship is also distinct from the recent trend of CEO activism. Byrd and Cooperman defined CEO activism as "corporate leaders speaking out on social and environmental policy issues not directly related to their company's core business" (Byrd \& Cooperman, 2014). While CEO activism, like financial censorship, can be a response to a controversial issue, there are several distinctions between the two. First, the CEO may come from any industry and not necessarily the financial sector. Second, CEO activism doesn't involve suppression of any financial transactions or the denial of services. Third, CEO activism is an individual expression rather than a business action.

What Are the Evolving Legal, Regulatory, Ethical, and Social Responsibility Frameworks for Financial Censorship in the U.S. Financial services Industry? (LO2)

The evolution from the traditional profit maximization or shareholder wealth maximization view to a modern multi-stakeholder value creation view is summarized in the Conceptual Analysis section. The priority or importance of each category in the modified Carroll (1979) model (see Case Table 2) has not significantly changed and we have concluded that firms with financial censorship in the priority 1 area (Economic) have less discretion and less risk than priority 4 (Discretionary). Hence, the modified Carroll model is used in DQ \#2 to discuss, integrate, and assess the legal, regulatory, ethical, and social responsibility frameworks for implications of the growing censorship controversy in today's changing social and political environment.

For example, the case indicates several financial services companies have voluntarily restricted the sales of legal products or services based on the values such transactions may promote. Payment processors like PayPal and Square did not allow their services to be used for the sale of firearms, firearm parts, or ammunition (PayPal, 2019; Square, 2019). Signature Bank and Stripe, respectively, closed the personal and campaign website accounts of President Trump (Kollmeyer, 2021; Andriotis, Rudegeair, \& Glazer, 2021). Following the Parkland, Florida, mass shooting, Citigroup required that its clients put in place processes to restrict the sale of guns to anyone under the age of 21 to stop the sale of high-capacity magazines and to perform background checks (Ross Sorkin, 2018a). We contend these voluntary social actions fit the definition of financial censorship in DQ \#1 but not all stakeholders in the financial industry have agreed to censor (not censor) these legal transactions.

Legal Framework. The legal framework matches the priority and type of responsibility (have to do) in Case Table 2 for analyzing this controversy, and centers on the U.S. Constitution and laws pertaining to 
privacy. Therefore, was financial censorship related to firearms transactions illegal under the Second Amendment of the U.S. Constitution?

The second article of the Bill of Rights states: "A well-regulated Militia, being necessary to the security of a free State, the right of the people to keep and bear Arms, shall not be infringed" (National Archives, 2019). The Second Amendment protects against severe limitations imposed by the federal, state, or local government on citizens' ownership of firearms. It does not mandate that private businesses have to approve financial transactions related to the sale of firearms or weapons. Hence, we conclude that limiting or banning payments for firearms purchases is a commercial decision and it is not unconstitutional.

The financial censorship issues in the case were not limited to firearms or one political view. Other examples of this controversial practice included transactions of other legal products like virtual or cryptocurrencies (Munkachy, 2018). Moreover, the case indicated financial institutions limited services to customers responsible for controversial speech or "hate speech." PayPal stopped processing payments for affiliated stores and donation pages for the website Gab.com (Rudegeair, 2019). The PayPal ban came after it was revealed that the suspect in the attack on a Pittsburgh synagogue in October 2018 appeared to have posted anti-Semitic notes on Gab's messaging platform (Rudegeair, 2019). Chase Bank closed the personal and business accounts of Texas conservative entrepreneur Enrique Tarrio, the Afro-Cuban chairman of the Proud Boys, without providing substantial and clear motivations (Malkin, 2019). The Council on American-Islamic Relations (CAIR) claimed racial or ethnic discrimination is an increasing trend, with bank account closure for customers who were the targets of risk investigations that may be motivated by the identifiable Muslim names or bank transactions with Muslim-majority countries and not any actual illegal activity (CAIR, 2017).

Thus, another pertinent Constitutional issue is whether financial censorship related to controversial speech is illegal under the First Amendment of the U.S. Constitution.

The first article of the Bill of Rights states: "Congress shall make no law respecting an establishment of religion, or prohibiting the free exercise thereof; or abridging the freedom of speech, or of the press; or the right of the people peaceably to assemble, and to petition the Government for a redress of grievances" (National Archives, 2019). The First Amendment only protects speech from government censorship. It applies to federal, state, and local governments; however, it does not include private citizens, businesses, and organizations (Nott, 2019).

From a federal legal perspective, private businesses have the right to refuse service to customers as long as they do not discriminate against protected classes. "The Title II of the Civil Rights Act of 1964 prohibits discrimination because of race, color, religion, or national origin in certain places of public accommodation, such as hotels, restaurants, banks and places of entertainment" (DOJ, 2015). Some states like California have greatly extended the protected classes to include ancestry, national origin, disability, medical condition, genetic information, marital status, sexual orientation, gender identity and expression, citizenship, primary language, or immigration status (California Civil Code, 2016). Therefore, it could be concluded under these laws that firearms sellers or buyers, individuals or organizations holding controversial political ideas, whether at the federal or state level, are not part of the legally protected classes and, therefore, financial services can take commercial decisions banning or restricting their products or services.

Regulatory Framework. This framework is related to and overlaps the legal category in Case Table 2 but focuses on the organizations responsible for monitoring and implementing the laws rather than the laws themselves. For example, banks, credit card companies, and payment processors depend on a complex system of federal and state regulators. Depending on the type of charter (national vs. state charter), the type of financial activity in which they engage (lending, mergers etc.), or the type of product/service offered, businesses in the financial industry are subjected to the rule-making, monitoring, and enforcing of a plethora of regulatory agencies, including the Office of the Comptroller of the Currency, the Federal Reserve System, the Federal Deposit Insurance Corporation (FDIC), the National Credit Union Administration, the Consumer Financial Protection Bureau (CFPB), and a collection of state financial agencies. Each agency has a different organizational structure, culture, and mission because the laws monitored and implemented 
are different. This decentralized regulatory structure might influence the structure of the financial industry as discussed in DQ \#4.

Lending activities are subject to the Equal Credit Opportunity Act (Regulation B; CFPB, 2018), which prevents discrimination in credit based on race, color, religion, national origin, sex, marital status, or age (provided the applicant has the capacity to contract); to the fact that all or part of the applicant's income derives from a public assistance program; or to the fact that the applicant has in good faith exercised any right under the Consumer Credit Protection Act. Hence, financial businesses can choose to limit or deny service to consumers as long as their decisions are not motivated by factors related to the protected categories listed in Regulation B.

The prior regulations are external in nature but what about self-regulation? Voluntary industry regulation might be deemed self-regulation and self-censorship. Hence, it could be easily argued that the activities of the Business Roundtable mentioned in the case are a form of self-regulation (Stefanadis, 2003; Solomon, 2010).

In some instances, financial censorship targeted businesses that may be considered edgy from a more traditional sense of morality. PayPal, JPMorgan Chase, Visa/Mastercard, and Square often denied or closed accounts of small businesses, artists, and independent contractors whose businesses were considered morally questionable because they were related to sex (Blue, 2015). For instance, PayPal froze accounts and seized funds belonging to Dee Dennis Tess Danesi, whose "transgression" was publishing the NYC Sex Blogger Calendar. Blogger and adult industry writer Cara Sutra was banned for selling a corset. Former escort Vicki Gallas was banned from using PayPal to process payments for her memoirs because they included sex work. In all these cases the organization claimed that the banning or denial of service was motivated by the assessment of "high risk" related to human sexuality. However, the FDIC clarified that such cases were not consistent with regulatory directives. Hence, in those cases, financial institutions adopted an unfair and expansive interpretation of financial regulations to justify a commercial decision and denial of service for legal activities.

In conclusion, the regulatory framework takes into account both external and internal regulations. The proper implementation of financial regulations cannot be normally used to justify the instances of financial censorships and such decisions are deemed commercial in nature, and may be understood using other frameworks. Therefore, banking regulations and industry self-regulation provide the framework for financial censorship regulation and each agency and organization might differ in its approach. Industry regulation has implications for innovation and industry governance as well as industry ethics (Stefanadis, 2003; Solomon, 2010).

Ethical Framework. "Values" are the centerpiece of ethics and ethics can be defined as the inner guiding beliefs, values, and moral principles that people use to interpret, decide, and analyze what is the appropriate and right way to behave (Jones \& George, 2019; Collins, 2019). The ethical framework is sometimes unclear because it overlaps with other frameworks. For example, the Carroll (1979) model in Case Table 2 initially categorized ethics (should do) together with discretionary (might do) as social responsibility. Ethical principles or concepts are usually associated with the way individuals and organizations make ethical decisions and each ethical scholar espouses a slightly different list of ethical concepts for decision-making that overlaps (Lawrence \& Weber, 2014; Jones \& George, 2019; Collins, 2019). The ethical concepts or categories identified by each scholar in the Conceptual Analysis could be used to assess the ethical behavior of companies when they decide to censor or not censor legal financial transactions.

Ethics is a large, interdisciplinary field of study, covering disciplines such as philosophy, religion, economics, law, and medicine, and business organizations are especially sensitive to the overlap between law and ethics (Lawrence \& Weber, 2014; Jones \& George, 2019; Collins, 2019). Many laws covering business today (i.e., Civil Rights, Labor Relations, Social Responsibility, and Financial Management) started as ethical concerns, issues, or movements and the conventional wisdom is that "all legal issues are ethical issues but not all ethical issues are legal issues." Collins (2019) indicated there are many circumstances in business where a decision is legal but unethical, which results in discomfort for all stakeholders affected by this decision. For example, in most states in the U.S., it is legal for a manager to 
share your resignation letter with co-workers. Also, employee use of company equipment such as computers to plan personal, non-work-related events may be legal but could be considered unethical (Lawrence \& Weber, 2014; Jones \& George, 2019; Collins, 2019). These actions might violate company policy but they are not necessarily illegal. In the area of finance, the previously mentioned Equal Credit Opportunity Act (Regulation B; CFPB, 2018), which prevents discrimination for credit based on race, color, religion, national origin, sex, marital status, or age (provided the applicant has the capacity to contract) owes its origin to the Civil Rights movement. Another area of overlap involves social engagement and the motivation that leads financial organizations to respond to ethical issues can be viewed from three perspectives - social obligation, social responsiveness, or social responsibility-but the values of the organization are the key (Kickul \& Lyons, 2012; Lawrence \& Weber, 2014; Jones \& George, 2019; Collins, 2019).

Hence, the item that differentiates the ethics framework from others is that voluntary actions taken by financial organizations to censor or not censor are based on the core "values" of the organization. Many organizations develop strategic plans with vision/mission statements supported by a list of the firm's core values (Rothaermel, 2015; Jones \& George, 2019; Collins, 2019). Moreover, Jones and George (2017) indicate that typical organizational responses to ethical dilemmas are shown in the following policies and company actions:

\section{Ethical codes of conduct \\ Ethical audits \\ - Ethics position in organizational structure \\ - Ethics training}

For example, the case reported PayPal stopped processing payments and donations for the website InfoWars, founded by the provocateur Alex Jones, accused of publishing discredited conspiracy theories (Rudegeair, 2019). The decision was taken after a PayPal company policy review "found instances that promoted hate or discriminatory intolerance against certain communities and religions, which run counter to our core value of inclusion" (Fung, 2018). Therefore, future financial censorship actions based primarily on the core values of organizations should be analyzed from the ethical framework.

Social Responsibility Framework. The strategic management literature suggests social responsibility leads to a higher and more sustainable position in the marketplace than actions taken due to either social obligation or social responsiveness (Rothaermel, 2015; Jones \& George, 2019; Collins, 2019). DQ \#1 pointed out that all transactions under the umbrella of financial censorship involve voluntary social actions and the strategic management literature covered in the Conceptual Analysis section suggests corporate social responsibility (CSR) involves the most discretion and risk for the organization and its stakeholder as compared to the legal, regulatory, and ethical frameworks. Thus, CSR could be substituted for the discretionary category in the modified Carroll (1979) model (see Case Table 2).

CSR goes beyond the core values of a firm and focuses on the goals and interests of each stakeholder. The case indicated that according to Ross Sorkin (2018b), some card processors like Square banned transactions involving legal firearms because they believed that permitting the sale of firearms on their platform was not consistent with their company values or in the best interest of their customers. The context was public reaction to mass shootings and customer safety, cost, and access, which were the main components as well as the advantages and disadvantages of financial censorship from the viewpoint of major customers. Other controversial financial transactions for financial organizations could be viewed from the perspective of key customers. Financial transactions related to other trends such as increase in terrorism threats, street demonstrations, and other social upheaval mentioned in the case could be analyzed from the customer's perspective. Several student stretch exercises involving multiple stakeholders and criteria for financial censorship are pertinent and mentioned in the Additional Teaching Approaches section but are beyond the intended scope of this question.

\section{Summary}

The traditional view of shareholder wealth maximization (profit) is appealing in terms of its simplicity; however, it is limiting and is losing favor among economics and management scholars. Hence, we have 
focused on frameworks that recognize the increasing importance of social value in financial transactions. The legal, regulatory, ethical, and social responsibility frameworks have merit for assessing the financial censorship controversy and have advantages and disadvantages. The modified Carroll (1979) model and other pertinent models provide the overall theoretical framework and the legal category (have to do) is the most compelling and popular; yet, there are gaps that need filling.

We concluded the U.S. Constitution and federal law do not preclude private citizens and businesses from limiting credit, banking privileges, and transaction processing to customers if they do not discriminate against legally protected classes. Hence, the voluntary financial censorship actions of financial institutions are legal. The regulatory viewpoint is similar to the legal approach because the primary stakeholder (government) derives its legitimacy from laws. The ethical (should do) and social responsibility (might do) frameworks are gaining in popularity due the focus on company values and emphasis on multiple stakeholders in business today, and gaps are covered more thoroughly in the Conceptual Analysis section and DQ \#3. When the ethical framework is appropriate, we suggest that students align the core values in the vision/mission statement of the company and the company ethical code of conduct to the ethically problematic financial transaction. If the values reflected in the problematic financial transaction conflicts with the core values, then the company may ban or not sanction the transaction. The example in the case was PayPal stopped processing payments and donations for the website Infowars, founded by the provocateur Alex Jones, accused of publishing discredited conspiracy theories (Rudegeair, 2019). If an ethical conflict or dilemma is involved, then we suggest using accepted ethical concepts to assess the ethical behavior of companies at the time the firm decides to censor or not censor legal financial transactions (Lawrence \& Weber, 2014; Jones \& George, 2019; Collins, 2019). We suggest students' social responsibility analysis focus on the customer as the most important stakeholder and our analysis is based on the customer perspective (see Table 5). Customer safety, cost, and access were used to determine the advantages and disadvantages of financial censorship transactions from the viewpoint of major customers.

These legal contexts are beyond the scope of DQ \#2; however, students might suggest state and international laws that contradict this conclusion. We argue that U.S. federal law supersedes state and international law in the U.S. Students might also raise the question of whether there is a disconnect between existing laws and public opinion. Richard Haythornthwaite stated his position in 2019 when he was Chairman of Mastercard: "If it is lawful, then we need to respect that transaction. If it is something that is swimming against the tide of society, it's for the society to rise up and change the law" (Credit-card firms are becoming reluctant regulators of the web, 2021).

Because the case is industry-focused rather than company-focused, students might also suggest other ethical approaches such as ethical audits, ethics position in organizational structure, and ethics training as more effective than ethical codes of conduct built around the company's core values. In that situation, we suggest a stretch project mentioned in the Additional Teaching Approaches for the student that compares the four ethical approaches prior to using it. Although customers are usually major stakeholders, the case suggested that interests of multiple stakeholders such as banks, credit card firms, transaction vendors, retail establishments, politicians, and individual U.S. citizens also need to be considered in the financial censorship controversy. The case also mentions that the Business Roundtable could be considered a separate and powerful industry stakeholder. Students might argue that an expanded stakeholder analysis is critical but it is beyond the intended scope of DQ \#2 and is touched upon in stakeholder question DQ \#3. Additionally, the stakeholder analysis involving the students' Dahlsrud (2008) model is also beyond the intended scope of DQ \#2 but was instead suggested as a stretch exercise in the Additional Teaching Approaches section.

\section{What Methods Can Be Used to Determine the Most Important Stakeholders in the Financial Industry Related to Legal Transactions That Have Been Curtailed or Banned? (LO 3)}

The role of stakeholders appears throughout the case as an integrating mechanism. Specifically, the multiple stakeholder perspective was a common thread running through the expansion of the scope of the financial censorship definition in DQ \#1 and the evolving frameworks in DQ \#2. Hence, the financial censorship controversy has grown in importance due in large part to the sheer number and variety of 
stakeholders that have voiced concerns about this phenomenon. One would expect the interests of financial institutions involved in financial censorship, their customers, and retail establishments involved in their transactions to have strong concerns about financial censorship. Yet, the case points out that politicians, government regulators, and special interest groups such as the Business Roundtable, social organizations, gun lobbyists, and political organizations have recently joined the controversy. The Conceptual Analysis section pointed out that it would be useful in any situation to identify primary and secondary stakeholders because primary stakeholders are more important and impactful (David, 2009; Jones \& George, 2019; Rothaermel, 2015; Wheelen \& Hunger, 2006). The case mentioned ten stakeholders and we used the Wheelen and Hunger (2006) three-step process of identifying direct, indirect, and degree-of-interest to classify the ten stakeholders into primary and secondary categories for the financial industry transactions covered by the case (see Table 3 ).

TABLE 3

PRIMARY AND SECONDARY STAKEHOLDERS IN THE FINANCIAL CENSORSHIP SPACE

\begin{tabular}{|l|l|}
\hline Primary & Secondary \\
\hline Financial institutions & Government regulators \\
\hline Stockholders & Politicians \\
\hline Credit card companies & Special interest groups \\
\hline Retail establishments & Managers/employees of companies \\
\hline Customers & Employees \\
\hline
\end{tabular}

Source: Authors' Notes, 2020

These ten stakeholders for the financial censorship controversy are not listed in priority order in Table 3 ; however, the usual suspects appear to fit in the proper primary and secondary categories. Research suggests that stakeholder attributes are the preferred techniques for determining the most important stakeholder (Eesley \& Lenox, 2005; Rothaermel, 2015). Seven non-prioritized stakeholder attributes are listed and defined in Table 4. For example, the Business Roundtable might rank high on power and rank middle to low on the other six factors in Table 4, resulting in an average overall six of ten priorities ranking of attributes (see Table 5). Other decision-makers could arrive at different rankings based on their unique perspectives and knowledge.

TABLE 4

\section{STAKEHOLDER ATTRIBUTE DEFINITIONS}

Power = Influence others to do something they would not otherwise do based on consequences

Legitimacy = Claims that are legally valid or otherwise appropriate or ethical

Urgency = Claims that require a firm's immediate attention and responses

Timing $=$ The date or interval that an action happens or is likely to happen

Control = Influence others to do something based on your ownership in the firm

Amount $=$ Tangible or intangible asset or liability

Risk $=$ Potential or actual adverse actions

Source: Authors' Notes, 2020 (adapted from Eesley \& Lenox, 2005; Rothaermel, 2015)

Rothaermel (2015) indicates that decision-makers should go through the five-step process to recognize and address stakeholders' claims and managers should pay attention to the list of attributes at each stage. The questions associated with each step are:

Step 1. Who are the stakeholders?

Step 2. What are the stakeholders' interests and claims?

Step 3. What opportunities and threats do the stakeholders present? 
Step 4. What legal, ethical, and philanthropic responsibilities does the firm have to the stakeholders (analysis frameworks in DQ \#2)?

Step 5. What should the firm do to address the stakeholders' concerns?

This step-by-step approach was used to select "customers" as the most important stakeholder from other stakeholders mentioned in the case. Stakeholder interests and consequences were added to the items that assist in prioritizing a list of stakeholders and determining the most important stakeholder. Based on tradition and equally weighted attributes, one might expect financial institutions to have the highest rank (1 $=$ high, $10=$ low $)$. However, we focused more on recent societal trends and the social responsibility framework, and implicitly gave more weight to the urgency and risk attributes when determining the priority ranking in Table 5.

TABLE 5

STAKEHOLDERS PRIORITY LIST

\begin{tabular}{|l|l|}
\hline Stakeholder & Priority Rank $(\mathbf{1}=\mathbf{H i g h , ~ 1 0}=\mathbf{L o w})$ \\
\hline Financial institutions & 2 \\
\hline Stockholders & 5 \\
\hline Credit card companies & 4 \\
\hline Retail establishments & 3 \\
\hline Customers & 1 \\
\hline Government regulators & 8 \\
\hline Politicians & 7 \\
\hline Special interest groups & 6 \\
\hline Managers/employees of companies & 9 \\
\hline Employees & 10 \\
\hline
\end{tabular}

Source: Authors' notes, 2020

The Conceptual Analysis mentioned the combination of stakeholder attributes, interests, and priorities, and quantitative decision analysis methods could be a more accurate method for finding the most important stakeholder. The expected value (EV) and weighted average decision matrix (WADM) methods would require different weights or probabilities for the importance of each attribute and weights or rankings to each stakeholder to determine the most important stakeholder involved in the financial controversy (Osland et al., 2007). Both EV and WADM are pertinent but beyond the intended scope of DQ \#3. However, the WADM method is described in Additional Teaching Approaches component of this IM as a student stretch exercise.

Stakeholders are an important integrating factor to understand and assess the financial censorship controversy, and we concluded that customers were the most important stakeholder in the financial industry. This would suggest the financial industry should view the controversy through the eyes of the typical customer. If sufficient information is available and ease of decision-making is most important, then the stakeholder synthesis methods mentioned in the Conceptual Analysis could be applied through the eyes of the customer (Goodpaster, 1991; Badaracco, 2016). If students are concerned about the authors' list of primary and secondary stakeholders as time-dependent and suffering from observer bias, then a student stretch exercise is mentioned in the Additional Teaching Approaches section suggesting other techniques to determine primary and secondary stakeholders. Students might also question the number of pertinent attributes (more or less than seven) mentioned in the authors' sample DQ \#3 response for the financial censorship controversy. Rather than use non-quantitative approaches, students with a quantitative bent might choose to use quantitative decision methods such as the WADM with additional information to determine the most important stakeholder. A student stretch exercise using the WADM method could be used to compare student responses with the authors' list of most important stakeholders in Table 5. 
What Are the Possible Consequences of Financial Censorship on Financial Services Industry Governance and the Company Organizational Structures and Procedures Necessary to Implement

Financial Censorship? (LO4)

Industry Governance (Structure). The Conceptual Analysis (CA) indicates that governance and structure usually refer to industry perspectives while organizational design and structure usually refer to individual company perspectives. Because the case emphasizes the financial industry perspective, we have relied on the theory related to governance (Stefanadis, 2003; MacKay \& Phillips, 2005; Solomon, 2010; Jones \& George, 2019). The CA suggests governance can be discussed from the bottom-up aggregation of businesses in strategic alliances and B2B networks around common interests (Jones \& George, 2019). Alternatively, top-down financial industry governance could be discussed from the perspective of various functional sub-units: e.g., banks, credit card companies, payment processors, and etc.; authority relationships such as centralization versus decentralization; or the amount and type of external and internal regulation. Some voluntary strategic alliances between payment processors, credit card companies, and banks have formed. For example, the case pointed out PayPal CEO Dan Shulman, made the final decision to deny service to users and also decided to elicit the help of outside groups like the Southern Poverty Law Center to provide a list of clients who would need to be considered for removal (Rudegeair, 2019). The CA indicated that new governance research suggests regulation theory is a better format for industry governance and we suggest it should be applied to the financial censorship controversy (Solomon, 2010). One example pointed out in the case is the involvement of the Business Roundtable to shape the multiple stakeholder approach and shareholder primacy is a form of top-down, industry voluntary self-regulation. Additionally, the regulation framework in DQ \#2 provides more context for financial industry governance.

We suggest a contingency approach for financial industry governance to take advantage of required and self-regulation as well as a combination of centralized and decentralized approaches. A centralized, industry-wide approach to financial censorship would provide consistency of treatment to customers and would lower legal, financial, and reputational risk to individual companies along with industry competition. The creation of a special board is one method to implement the centralization of authority concerning financial censorship. Industry players usually prefer decentralized approaches that provide perceived autonomy and control. The previously mentioned voluntary strategic alliances is an attractive, a selfregulation approach. Yet, when inconsistency in financial censorship impacts the legal status of stakeholders or unfair treatment, centralization in the industry is suggested. After workable industry standards are developed, articulated, understood, and effectively implemented, the preferred industry process of decentralization could be used.

Organization Design (Structure). One structural approach might not fit all organizations and the nuanced, high-profile, high-risk, and controversial nature of financial censorship in most organization lends itself to a decentralized approach. Companies often develop centralized departments such as Chief Ethical Officer, VP of Diversity and Inclusion, and Crisis Transition Manager that report directly to the CEO until the unique and controversial issues are sorted out and then decentralized when they become less risky and become an everyday company activity. However, we strongly suggest that selection of the best structural approach mitigates these risks. Moreover, the case examples point out the nuanced, controversial financial censorship needs to be integrated with the strategic goals of each company. The strategic goals of each company are likely to be different and the external legal, ethical, and social responsibility forces as well the unique internal culture argue for a differentiated, decentralized structure. A plethora of organizational designs, such as functional, product, customer, territory, project teams and etc., exist to implement these differentiated, decentralized structures (Mintzberg, 1993; Trice \& Beyer, 1993; Osland et al., 2007; Jones $\&$ George, 2019). Typically, financial decisions and recommendations are made in the finance and accounting functions of an organization where specialized expertise exists. When there is a strong potential for legal or public relations exposure, these functional areas could get involved as major players on a project team basis. PayPal relied on a brand-reputation internal group comprised of representatives from their regulatory, compliance, legal, and corporate affairs teams to decide whether a user violated the firm's values and policies. The group routinely removed up to 100 accounts a month for promoting hate and intolerance. 
CEO Dan Shulman made the final decision to deny service to users. This is an example of a decentralized approach to organizational design based on company strategy, skill, resources, and authority.

Summary. Numerous management scholars have noted that no organization design is perfect and any design can suffer from a variety of problems that develop due to the design itself (Mintzberg, 1993; Trice \& Beyer, 1993; Osland et al., 2007). It is worth recognizing that alternatives, such as required versus selfregulation and centralized versus decentralized structures, have advantages and disadvantages and we suggested a contingency approach. We suggested a combination of required regulation and voluntary selfregulation that drive industry governance and decentralized organizational designs at the firm level. Alternatively, we suggested a decentralized approach to structure at the firm level.

In the class discussion, opponents of financial censorship and centralization of authority alike might point out that removing the burden of decision-making from individual firms could ensure more independence but also would increase homogeneity in the sector and stifle the diversity of product offerings and competition. Students are also likely to point out examples of industry-wide standards failures in other industries. These students are likely to point out research covered in our CA to suggest that the lack of a coherent strategy and supporting culture usually results in failed industry and organizational structures (Mintzberg, 1993; Trice \& Beyer, 1993; Osland et al., 2007). This is beyond the intended scope of DQ \#4; however, one way to address this concern is to encourage students to do the stretch exercise asking the students to develop a systematic, comparative industry study to discover whether strategy and culture differentiated successful companies and industries.

What Are the Possible Consequences of Financial Censorship on Financial Innovation, Customers' Privacy, and Competition in the U.S. Financial Services Industry? (LO5)

Monitoring Transactions. In order to implement effective financial censorship, banks, credit cards companies, and payment processors would need to increase the amount of data they collect about the products or services transacted and the social media footprint of their customers. To be able to monitor the types of purchases on the financial network, the Merchant Category Codes (MCCs) should be revised to have finer definitions about the nature of the merchant. Most likely, the MCC system would not be appropriate for large retailers that sell a mix of firearms, sporting goods, or other consumer products; therefore, a standardized database of SKU-level data would need to be developed (Ross Sorkin, 2018b). SKU codes refer to the stock-keeping unit number of an item. Hence, each financial institution would collect the specific details of any item purchased by a consumer with each swipe of a card or purchasing click on a website.

The creation of such a new system for the collection and monitoring of terabytes or petabytes of data may be opposed by the merchants themselves out of a fear that financial services companies could sell the information or use it to steer customers to rival merchants (Ross Sorkin, 2018b). In some cases, financial institutions could also decide to ban any transactions within a virtually geo-fenced area using GPS coordinates. For instance, credit card companies could decline any transaction originating from a GPSdefined area where a gun show is held during a given time (Ross Sorkin, 2018a). Hence, financial institutions would need to monitor the location of their customers. The implications for customers' and merchants' privacy would be significant as the financial industry would be able to monitor, at the most refined level, the economic and financial lives of millions of individuals and businesses. Such databases would also certainly be the objects of cyberattacks by hackers eager to steal such rich troves of information.

Monitoring Speech. Detecting customers whose speech violates a company's terms of service is a technological challenge. For example, hate speech is difficult to detect both because of the large volume of speech that takes place and the vague definition. While some countries have explicit laws that define and ban hate speech, the U.S. does not. Therefore, U.S. firms that want to financially censor hate speech take on the burden themselves. Detecting violations can be done proactively or reactively (Tusikov 2019). Developing AI algorithms to detect hate speech online in social media is an active area of research (Gitari et al., 2015; Gao et al., 2017; Cao et al., 2020; Paschalides et al., 2020). To date, even the best of these algorithms misses $5 \%$ or more of the samples of hate speech on which they are tested. They also mistakenly 
classify acceptable speech as hate speech at a similar rate. Therefore, human reviewers will need to be a part of the speech evaluation process for the foreseeable future.

Companies such as Patreon manually review content created by their customers to decide whether it violates their terms of service (Bowles, 2018). AI can be used in conjunction with human review, with the AI algorithms flagging posts for further review by humans. Some companies have also relied on outside experts to help distinguish hate speech from allowable forms of speech (Rudegeair, 2019).

A reactive approach does not rely on constant monitoring of content. Instead, stakeholders bring problematic speech to the company's attention and the company then investigates and decides whether the speech is allowable or not. Technology plays a role here as well. For example, to comply with European Union (EU) laws, online platforms proposed the development of a shared database of content that they have previously removed in order to speed the detection of it in case it is reposted on another platform (Keats Citron, 2018). Also, U.S. firms might adopt this approach.

The reasons financial institutions provide for terminating relationships with customers based on their speech vary. For example, credit card companies in their terms of service reserve the right to discontinue service to any customer whose speech would hurt the credit card company's reputation (Henn, 2013). On the other hand, PayPal has terminated relationships with customers whose speech violates PayPal's "principles" (Tusikov, 2019). Patreon has an explicit list of what types of speech are and are not allowed.

Cryptocurrency. In addition to the creation of new database and monitoring technologies relying on artificial intelligence and machine learning, effective financial censorship could speed up the adoption by consumers of new payment technologies like cryptocurrencies (Devoe, 2019). Cryptocurrencies, such as Bitcoin, are based on encrypted and decentralized peer-to-peer networks known as "blockchains" (Yermack, 2017). Merchants or consumers, fearing that their transactions would be limited by the arbitrary decisions of financial services companies, might retreat from a transparent and well-regulated financial system and gravitate toward an anonymous payment system based on cryptocurrencies. Moreover, because many financial service companies have banned the purchase or sale of cryptocurrencies (Munkachy, 2018), customers could choose to exit the traditional banking and payment system, rendering ineffective any attempt to implement wide-spread social changes through financial censorship.

A number of individuals who have experienced financial censorship have already turned to cryptocurrencies (Birch, 2019). In the process, they have revealed some of the limitations of cryptocurrencies as a means of avoiding financial censorship. Currently, cryptocurrencies as an alternative to the traditional financial system are limited by the fact that they are not widely accepted as a form of payment (Sater, 2019). Users of cryptocurrencies may not be immune to financial censorship because although the blockchain itself may be decentralized, many cryptocurrency users rely on private companies to store their cryptocurrency and to convert their cryptocurrency to USD or another currency. In one instance, the cryptocurrency exchange Coinbase reportedly closed the account of someone associated with controversial speech (Zmudzinski, 2019). The blockchain has been proposed as a valuable tool for the cannabis industry as it can be used not only for financial transactions but also to trace products through the supply chain as required by law. Yet cannabis companies have found that the use of cryptocurrency may create more problems than it solves (Sater, 2019).

Competition. The impact of financial censorship on the competitive environment of the financial sector could be significant. An industry-wide approach with industry standards (see DQ \#4) could mitigate some of the dislocations that are likely to result from each company in the industry going its own way. Technical innovations without industry standards may exacerbate the financial censorship controversy and industry confusion. Customers could select their financial institutions based on the social values they espouse, thereby creating a Balkanized industry where financial institutions are chosen not primarily for their level of service, transaction costs, and efficiency but because they cater to a specific political or social ideology and they ban or allow certain transactions. Consumers that oppose firearm sales could gravitate toward PayPal, whereas consumers who champion the second amendment could select payment networks like Visa that do not consider themselves in the "position of setting restrictions on the sale of lawful goods or services" (Ross Sorkin, 2018b). Therefore, with time, social value and political affiliation could become salient considerations in explaining financial decisions. 


\section{Epilogue}

Some recent notable examples since the spring 2021 cutoff date for our case are the interpretation that credit card payment for abortions are "providers of abortions" under the September 2021 Texas Abortion law passage and Mastercard's October 15 requirement of age verification for adult websites and social media. Some issues that appear to be financial censorship have been handled under existing laws and banking regulations, and other actions such as OnlyFans' decision to drop adult content and Michael Flynn's Chase Bank account closure were moot because they were reversed. Nevertheless, the boundaries of financial censorship of legal transactions continue to evolve in scope and complexity while the intensity and breadth of the controversy also grows as new dilemmas emerge.

\section{REFERENCES}

Andriotis, A., Rudegeair, P., \& Glazer, E. (2021, January 10). Stripe Stops Processing Payments for Trump Campaign Website. The Wall Street Journal. Retrieved from https://www.wsj.com/articles/stripe-stops-processing-payments-for-trump-campaign-website11610319116 ?mod=article_inline

Argyres, N.S. (1995). Technology strategy, governance structure and interdivisional coordination. Journal of Economic Behavior \& Organization, 28(3), 337-358.

Asher, C.C., Mahoney, J.M., \& Mahoney, J.T. (2005). Towards a property rights foundation for a stakeholder theory of the firm. Journal of Management \& Governance, 9(1), 5-32.

Bambauer, D.E. (September 9, 2012) Censorship V3.1. IEEE Internet Computing 26 (May/June 2013); Arizona Legal Studies Discussion Paper No. 12-28. Retrieved from https://ssrn.com/abstract=2144004

Birch, J. (January 23, 2019). Controversial Content Creators Shift to Crypto after Censorship. Cointelegraph. Retrieved from https://cointelegraph.com/news/controversial-content-creatorsshift-to-crypto-after-censorship

Blue, V. (2015, December 2). PayPal, Square and big banking's war on the sex industry. The Engadget. Retrieved from: https://www.engadget.com/2015-12-02-paypal-square-and-big-bankings-war-onthe-sex-industry.html

Bowles, N. (December 24, 2018). Patreon Bars Anti-Feminist for Racist Speech, Inciting Revolt. The New York Times. Retrieved from https://www.nytimes.com/2018/12/24/technology/patreon-hatespeech-bans.html

Bunn, M. (2015). Reimagining repression: New censorship theory and after. History and Theory, 54(1), $25-44$.

Byrd, J., \& Cooperman, E.S. (2014). Let's talk: an analysis of the "vote vs. negotiated withdrawal" decision for social activist environmental health shareholder resolutions. Journal of Sustainable Finance \& Investment, 4(3), 230-248. Retrieved from http://www.hbs.edu/faculty/Publication\%20Files/16-100._0fc0baf0-1735-47f2-a2c382e304e6e990.pdf.

CAIR. (2017, October 21). Civil Rights Report 2017: Bank Account Closures. U.S. Islamophobia Network. Retrieved from http://www.islamophobia.org/islamophobic-individuals/stevenemerson/15-reports/198-civil-rights-report-2017-bank-account-closures.html

California Civil Code. (2016, January 1). California Civil Code: Section 51. Retrieved from http://leginfo.legislature.ca.gov/faces/codes_displaySection.xhtml?lawCode=CIV\&sectionNum= 51

Cao, R., Lee, R.K.W., \& Hoang, T.A. (2020, July). DeepHate: Hate Speech Detection via Multi-Faceted Text Representations. In 12th ACM Conference on Web Science (pp. 11-20).

Carroll, A.B. (1979). A three-dimensional conceptual model of corporate performance. Academy of Management Review, 4(4), 497-505.

CFPB (2018). Equal Credit Opportunity Act. 12 CFR Part 1002 (Regulation B). Retrieved from https://www.consumerfinance.gov/policy-compliance/rulemaking/regulations/1002/ 
Collins, D. (2019). Business ethics (2nd Ed.). Newbury Park, CA.: Sage Publishers.

Credit-card firms are becoming reluctant regulators of the web. (2021, October 10). The Economist. Retrieved from https://www.economist.com/finance-and-economics/credit-card-firms-arebecoming-reluctant-regulators-of-the-web/21805450

Dahlsrud, A. (2008). How corporate social responsibility is defined: An analysis of 37 definitions. Corporate Social Responsibility and Environmental Management, 15(1), 1-13.

David, F. (2009). Strategic Management: Concepts and Cases (12th ed). Upper Saddle River, NJ: Pearson Prentice Hall.

Devoe, R. (2019, April 17). Chase bank accused to "de-banking" accounts due to customer's political views. Blockonomi. Retrieved from: https://blockonomi.com/chase-bank-accused-de-bankingaccounts-political-views/

DOJ. (2015, August 6). Title II of the Civil Rights Act (Public Accommodations) Department of Justice, Civil Right Division. Retrieved from https://www.justice.gov/crt-22

Eesley, C., \& Lenox, M.J. (2005, August). Firm Responses to Secondary Stakeholder Action. In Academy of Management Proceedings (Vol. 2005, No. 1, pp. E1-E6). Academy of Management.

EFF. (2020). Financial Censorship. Retrieved from https://www.eff.org/issues/financial-censorship

Elkington, J. (2018, June 25). 25 years ago I coined the phrase "triple bottom line." Here's why it's time to rethink it. Harvard Business Review. Retrieved from https://hbr.org/2018/

Freeman, R.E. (1984). Strategic planning: A stakeholder approach. Pitman, Boston.

Freshwater, H. (2004). Towards a redefinition of censorship. In Censorship \& Cultural Regulation in the Modern Age (pp. 217-237). Brill Rodopi.

Friedman, M. (1970). A Friedman doctrine: The social responsibility of business is to increase its profits. The New York Times Magazine, 13(1970), 32-33.

Friedman, M. (2009). Capitalism and freedom. University of Chicago press.

Fung, B. (2018, September 21). PayPal bans Alex Jones, saying Infowars 'promoted hate or discriminatory intolerance'. The Washington Post. Retrieved from https://www.washingtonpost.com/technology/2018/09/21/paypal-bans-alex-jones-sayinginfowars-promoted-hate-or-discriminatory-intolerance/?noredirect $=$ on

Gao, L., Kuppersmith, A., \& Huang, R. (2017). Recognizing explicit and implicit hate speech using a weakly supervised two-path bootstrapping approach. arXiv preprint arXiv:1710.07394.

Gitari, N.D., Zuping, Z., Damien, H., \& Long, J. (2015). A lexicon-based approach for hate speech detection. International Journal of Multimedia and Ubiquitous Engineering, 10(4), 215-230.

Goodpaster, K. (1991, January). Business Ethics and Stakeholder Analysis. Business Ethics Quarterly, l(1), 53-73.

Henn, S. (November 6, 2013). Credit Cards under Pressure to Police Online Expression. National Public Radio. Retrieved from https://www.nhpr.org/post/credit-cards-under-pressure-police-onlineexpression\#stream/0

Hoffmann, F.W. (1989). Intellectual Freedom and Censorship: An Annotated Bibliography. Scarecrow Press.

Jamali, D. (2008). A stakeholder approach to corporate social responsibility: A fresh perspective into theory and practice. Journal of business ethics, 82(1), 213-231.

Jones, G., \& George, J. (2019). Essentials of contemporary management. New York, NY: McGraw-Hill Irwin.

Kaplan, R., \& Norton, D. (1996). Using the balanced scorecard as a strategic management system. Boston MA: Harvard Business School Press.

Keats Citron, D. (2018). Extremist Speech, Compelled Conformity, and Censorship Creep. Notre Dame Law Review, 93(3), 1035.

Keating, F. (2014, April 24). Justice Puts Banks in a Choke Hold. Wall Street Journal. Retrieved from https://www.wsj.com/articles/frank-keating-justice-puts-banks-in-a-choke-hold1398381603 ?tesla $=\mathrm{y}$. 
Kickul, J., \& Lyons, T.S. (2012). Understanding Social Entrepreneurship: The Relentless Pursuit of Mission in an Ever Changing World. New York, NY: Routledge, Taylor \& Francis Group

Kollmeyer, B. (2021, January 12). Trump reportedly dumped by lenders Deutsche Bank and Signature. MarketWatch. Retrieved from https://www.marketwatch.com/story/banks-that-have-donebusiness-with-trump-start-to-distance-themselves-11610444427

Kreimer, S.F. (2006). Censorship by proxy: The First Amendment, internet intermediaries, and the problem of the weakest link. U. Pa. L. Rev., 155, 11. Retrieved from https://scholarship.law.upenn.edu/cgi/viewcontent.cgi?article=1126\&context=faculty_scholarship

Laasch, O., Suddaby, R., Freeman, R.E., \& Jamali, D. (Eds.). (2020). Research Handbook of Responsible Management. Edward Elgar Publishing.

Lawrence, A., \& Weber, J. (2014). Business and society: Stakeholders, ethics, public policy (15th ed.). New York: NY: McGraw-Hill Education.

Leetaru, K. (2019, August 22). Gatekeeping Is Not the Same as Censorship. Forbes. Retrieved from https://www.forbes.com/sites/kalevleetaru/2019/08/22/gatekeeping-is-not-the-same-ascensorship/\#512d76f7411a.

MacKay, P., \& Phillips, G.M. (2005). How does industry affect firm financial structure? The Review of Financial Studies, 18(4), 1433-1466.

Malkin, M. (2019, April 17). Are Chase Bank's Account Decisions Motivated by Politics? The Daily Signal. Retrieved from https://www.dailysignal.com/2019/04/17/are-chase-banks-accountdecisions-motivated-by-politics/

McWilliams, A., Siegel, D.S., \& Wright, P.M. (2006). Corporate social responsibility: Strategic implications. Journal of Management Studies, 43(1), 1-18.

Mintzberg, H. (1993). Structure in fives: Designing effective organizations. Englewood Cliffs, New Jersey: Prentice Hall.

Munkachy, A. (2018, July 18). 20+ Banks that Have Banned Cryptocurrency Trades with Credit Cards. CoinIQ. Retrieved from https://coiniq.com/banks-that-banned-cryptocurrency/

National Archives, (2019). America's Founding Documents. The Bill of Rights: A Transcription. Retrieved from: https://www.archives.gov/founding-docs/bill-of-rights-transcript

Nott, L. (2019). Is Your Speech Protected by the First Amendment? Freedom Forum Institute. Retrieved from https://www.freedomforuminstitute.org/first-amendment-center/primers/basics/

Osland, J.S., Kolb, D.A., Rubin, I.M. \& Turner, M.E. (2007). Organizational behavior: An experiential approach. Upper Saddle River, New Jersey: Pearson-Prentice-Hall.

Paschalides, D., Stephanidis, D., Andreou, A., Orphanou, K., Pallis, G., Dikaiakos, M.D., \& Markatos, E. (2020). MANDOLA: A big-data processing and visualization platform for monitoring and detecting online hate speech. ACM Transactions on Internet Technology (TOIT), 20(2), 1-21.

PayPal. (2019). What is PayPal's policy on transactions that involve firearms? Retrieved from https://www.paypal.com/us/smarthelp/article/What-is-PayPal\%E2\%80\%99s-policy-ontransactions-that-involve-firearms-FAQ585

Project Veritas. (April 16, 2019). DEBANKING: Chase Bank Says "moral character" a Reason Why They Don't Do Business with "those types of people". Retrieved from https://www.projectveritas.com/2019/04/16/debanking-chase-bank-says-moral-character-areason-why-they-dont-do-business-with-those-types-of-people/

Ross Sorkin, A. (2018a, March 26). Citigroup Acted. Now, Two New Ideas on How Banks Can Limit Gun Sales. The New York Times. Retrieved from https://www.nytimes.com/2018/03/26/business/citigroup-guns.html

Ross Sorkin, A. (2018b, December 28). How credit cards are used to finance mass shootings. The New York Times. Retrieved from https://www.nytimes.com/interactive/2018/12/24/business/dealbook/mass-shootings-creditcards.html?module $=$ inline

Rothaermel, F.T. (2015). Strategic Management Concepts (4e). New York, NY: McGraw Hill. 
Rudegeair, P. (2019, February 24). PayPal CEO Grapples with Fringe Groups. The Wall Street Journal. Retrieved from https://www.wsj.com/articles/paypal-ceo-grapples-with-fringe-groups11551016800

Sater, S. (2019). Banking Cannabis. Retrieved from https://papers.ssrn.com/sol3/papers.cfm?abstract_id=3365132

Solomon, J.M. (2010). New governance, preemptive self-regulation, and the blurring of boundaries in regulatory theory and practice. Wis. L. Rev., 591.

Square. (2019). Prohibited Goods and Services with Square Point of Sale. Retrieved from https://squareup.com/help/us/en/article/5089-prohibited-goods-and-services-with-square-point-ofsale

Stefanadis, C. (2003). Self-regulation, innovation, and the financial industry. Journal of Regulatory Economics, 23(1), 5-25.

Trice, H.M., \& Beyer, J.M. (1993). The cultures of work organizations. Englewood Cliffs, NJ: PrenticeHall, Inc.

Tusikov, N. (2019). Defunding Hate: PayPal's Regulation of Hate Groups. Surveillance \& Society, $17(1 / 2), 46-53$.

Wheelen, T., \& Hunger, D. (2006). Concepts in strategic management \& business policy, 10th (10th Ed.). Upper Saddle River, NJ: Pearson Prentice Hall.

$\mathrm{Wu}, \mathrm{T}$. (2006). The world trade law of censorship and internet filtering. Chi. J. Int'l L., 7, 263. Retrieved from https://chicagounbound.uchicago.edu/cgi/viewcontent.cgi? article=1243\&context=cjil

Yermack, D. (2017). Corporate governance and blockchains. Review of Finance, 21(1), 7-31.

Zmudzinski, A. (2019, January 5). Coinbase Reportedly Bans Personal Account of Social Media Platform Gab Founder. Cointelegraph. Retrieved from https://cointelegraph.com/news/coinbasereportedly-bans-personal-account-of-social-media-platform-gab-founder 